Kader

e-ISSN: 2602-2710

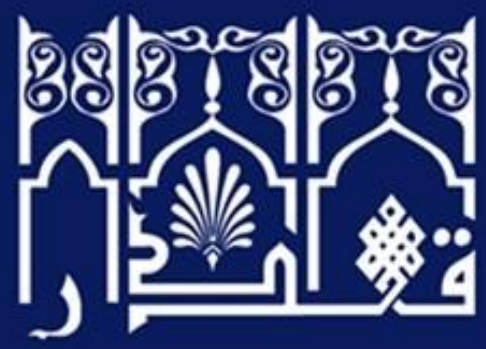

Cilt: 19, Say1: 2, 2021, ss. 645-677｜Ｖolume: 19, Issue: 2, 2021, pp. 645-677

\title{
Üniversite Öğrencilerinin Kader Algıları: Metaforik Bir Araştırma
}

The Perception of Fate (Qadar) among the University Students: A Metaphorical Analysis

\section{Mebrure DOĞAN}

Doç. Dr., Afyon Üniversitesi, İlahiyat Fakültesi, Afyonkarahisar/Türkiye Associate Professor Dr., Afyon University, Faculty of Theology, Afyonkarahisar/Türkiye mebruredogan@gmail.com | orcid.org/0000-0002-9027-144X | ror.org/03a1crh56

\author{
Makale Bilgisi Article Information \\ Makale Türü Article Type \\ Araştırma Makalesi Research Article \\ Geliş Tarihi Date Recieved \\ 15 Ekim $2021 \quad 15$ October 2021 \\ Kabul Tarihi Date Accepted \\ 28 Aralk $2021 \quad 28$ December 2021 \\ Yayın Tarihi Date Published \\ 31 Aralik 202131 December 2021 \\ İntihal Plagiarism
}

Bu makale, iTenticate yazılımı ile taranmıştır. İntihal This article has been scanned with iTenticate

tespit edilmemiştir. software. No plagiarism detected.

Etik Beyan Ethical Statement

$\mathrm{Bu}$ çalı̧̧manın hazırlanma sürecinde bilimsel ve etik It is declared that scientific and ethical principles ilkelere uyulduğu ve yararlanılan tüm çalışmaların have been followed while carrying out and writing kaynakçada belirtildiği beyan olunur (Mebrure this study and that all the sources used have been Doğan). properly cited (Mebrure Doğan).

CC BY-NC-ND 4.0 lisansı ile lisanslanmıştır. Licensed under CC BY-NC-ND 4.0 license. Araştırma”. Kader 19/2 (Aralı 2021), 645-677. 


\section{Öz}

Kader hem çoğu dinde yer alan bir inanç konusu hem de yaşamsal bir olgu olarak hayatın içinde hep var olagelmiştir. Kaderin bilinmeyen yönleri ve kaderle ilgili belirsizlikler ise insanın merak duygusunu daima canlı tutan bir unsur olmuştur. Kader algılarının hayatı etkileme potansiyeli yüksektir. Bireyin kader algısı hayata bakışını belirleyen unsurlardan biri olduğu gibi davranışlarını da etkilemektedir. Kader algılarının insan davranışlarını etkileme gücü, araştırmanın konusunun belirlenmesinde etkili olmuştur. Araştırmanın konusu "kader algısı" olarak belirlenmiş, örneklem grubu olarak üniversite öğrencileri seçilmiştir. Araştırma, fenomenolojik olgu bilim yöntemine dayalı metafor analizi tekniğiyle gerçekleştirilmiştir. Kaderle ilgili doğrudan sorular sormak yerine bu yöntemin tercih edilmesinin nedeni gençlerin zihinlerinin derinliklerinde yer alan gerçek düşüncelere ulaşmaktır. Farklı üniversitelerin farklı bölümlerinden lisans öğrencileriyle gerçekleştirilen araştırmaya 211 öğrenci katılmış, uygun olmayan veriler ayıklandığından 163 veri seti ile analize devam edilmiştir. Öncelikle metaforlarda kadere yüklenen anlamlara göre aynı temayı içeren gruplar oluşturulmuş, gruplamada metafordan ziyade onu açıklayan "çünkü..." kısmı esas alınmıştır. Kategoriler ve altında toplanan temalardaki metaforlar ilişkisel açıdan yeniden gözden geçirilmiş ve sonrasında geçerlilik ve güvenirliğin sağlanması için çalışma iki uzman tarafından incelenmiştir. Araştırmada sonuç olarak bazı katılımcıların metafor üretirken kaderle ilgili problemlerin zihinlerindeki karşılıklarına açıklık getirmeye ve kavramsal olarak kaderi tanımlamaya çalıştıkları belirlenmiştir. Metaforları oluştururken kimi katılımcıların kaderi dinî inançlarla ilişkilendirdikleri kimi katılımcıların ise dinden bağımsız ele aldıkları görülmüştür. Üniversite öğrencilerinin "kader" kavramına ilişkin 106 metafor ürettiğinin tespit edildiği araştırmada en sık tekrarlanan metafor "yol" metaforudur. Bunu "kitap" ve "çark" metaforları izlemektedir. "Senaryo, kalem, harita, yol ayrımı, sığınak, çizgi, gemi” metaforları ise en fazla tercih edilen ilk on metafor arasındadır. Araştırma kapsamında üretilen metaforların açılamaları incelendikten sonra metaforlar ortak özellikleri bakımından gruplandırılmış, temalar oluşturulmuş, temalar da kendi aralarında gruplandırılarak kategoriler oluşturulmuştur. Buna göre birinci kategori "nitelik bağlamında kader" olup alt temaları "değişmeyen/belirlenmiş olgu olarak kader, yönlendirilebilen/tercih edilebilen olgu olarak kader, bilinmeyen/kontrol edilemeyen olgu olarak kader, hem belirlenmiş hem de yönlendirilebilen olgu olarak kader ve savunma mekanizması olarak kader" olarak belirlenmiştir. İkinci kategori "inanç-özgürlük bağlamında kader" dir. Bu kategorinin alt temaları ise "fatalist eğilimli kader olgusu, salt inanç temelli kader olgusu, inanç temelli iradeci kader olgusu, inanç temelli cebrî kader olgusu, inanç temelli olmayan iradeci kader olgusu ve kader karşıtlığı" olarak belirlenmiştir.

Anahtar Kelimeler: Din psikolojisi, Kader algıları, Kader inancı, Fatalizm, Metafor, Atıf/Yükleme.

\section{Abstract}

Fate has always existed in life both as a faith issue appearing in most of the religions and as a vital phenomenon. The unknown sides of fate and the uncertainties related to fate have been a factor that always keeps a human's sense of curiosity alive. The fate perceptions' potential of affecting life is high. As an individual's fate perception is one of the factors determining his attitude to life, and it also affects his behaviours. The fate perceptions' power of influencing human behaviours was effective in specifying the research topic. The subject of the research was determined as "fate perception", and university students were selected as the sample group. The research was carried out through metaphor analysis technique based on the phenomenological method. The reason for referring this method rather than directly asking questions related to fate is to reach the real thoughts in the depths of youths' minds. A total of 211 students participated in the study performed with undergraduate students from different departments of different universities, and the analysis was continued with 163 data sets since the inappropriate data were sorted out. First of all, groups that included the same theme according to the meanings attributed to the fate in the metaphors were formed, and rather than the metaphor, the "because..." part that described it was based on in the grouping. The categories and the metaphors collected in the themes under them were again reviewed relationally, and then the research was analysed by two specialists to ensure the validity and reliability. As a result of the research, it was determined that some of the participants tried to clarify equivalents of the problems related to fate in their minds and to conceptually define the fate while producing metaphors. It was seen that some of the participants associated the fate with religious beliefs in forming metaphors while some of them dealt with it separately from the religion. The most frequently repeated metaphor is the "path" metaphor in the study, in which university students were found to have produced 106 metaphors related to the concept of "fate". This is followed by the metaphors "book" and "wheel". "Scenario, pen, map, crossroads, bunker, line, ship" metaphors are among the top ten most preferred metaphors. After the explanations of the metaphors produced in the scope of the research were examined, they were grouped in terms of their common features, themes were formed, and categories were formed by grouping the 
themes among themselves. Accordingly, the first category was identified as "fate in the context of characteristic" and its sub-themes were "fate as a(n) unchanging/determined phenomenon, fate as a divertible/preferable phenomenon, fate as an unknown/uncontrollable phenomenon, fate as both determined and divertible phenomenon and fate as a defence mechanism". The second category was "fate in the context of faith/freedom". The sub-themes of this category were determined as "the phenomenon of fatalist-inclined fate, the phenomenon of pure faith-based fate, the phenomenon of faith-based voluntaristic fate, the phenomenon of faith-based Cebrî fate, the phenomenon of not faith-based voluntaristic fate, fate contrast".

Keywords: Psychology of religion, Fate perceptions, Faith of fate, Fatalism, Metaphor, Attribution.

\section{Giriş}

İlk çağdan modern çağa kadar insanların ilgi odağı olan kader, varoluşsal anlamda belirsizliklerin ve bilinmeyenlerin çok olduğu konuların başında gelmektedir. Kader nedir? Yüce bir kudret veya doğaüstü bir güç tarafından önceden belirlenmiş midir? İnsan kendi kaderinde söz sahibi midir? gibi soruların cevapları teolojide hep tartışılmıştır. Hatta bu konudaki teolojik tartışmalar, inanç mezheplerinin doğuşuna zemin hazırlamıştır. Diğer taraftan kader, dinî bağl1lıktan bağımsız olarak hayatın içinde var olan yaşamsal olgulardandır.

Kader hakkındaki düşünceleri, bireylerin kader algılarını oluştururken kader algıları da hayat perspektiflerini belirlemektedir. Hayatta seçimler önemlidir ve kader algısı bu seçimlerde yön belirleyici olabilmektedir. İnsanın kendi eylemleriyle ilgili sorumluluk alıp almaması kader algısıyla ilişkili olabileceği gibi sorumluluk almak istememesi durumunda kaderi sığınılacak bir liman gibi görmesi de bu algılla ilişkilidir. Bireylerin yaşama bakışları, başına gelen hadiseleri değerlendirip yorumlamaları, problem çözme biçimleri, hatta psikolojik iyi oluşları, kadere yükledikleri anlamdan etkilenmektedir. Dolayısıyla kader algılarının hayatı etkileme potansiyeli ile birlikte kader konusundaki zihinlerdeki bulanıklık, bu konuda yapılacak akademik çalışmalara ihtiyacı kendiliğinden ortaya çıarmaktadır.

Kader olgusu ülkemizde din psikolojisi alanında çeşitli araştırmalara konu olmuştur. Yaparel'in depresyon ve dinî inançlar ile tabiatüstü nedensel yüklemeler arasındaki ilişkiyi konu alan araştırması (1994), Karaca'nın kader inancının psikoterapik fonksiyonunu araştırdığı çalışması (2006), Kara'nın öğrenilmiş çaresizlik ile kader inancı arasındaki ilişkiyi ele aldığı çalışması(2009), Kartopu'nun kader algıları ile kaygı arasındaki ilişkileri incelediği araştırması (2012), Kilit'in kader algısı ile psikolojik iyi oluş arasındaki ilişkileri ele aldığı araştırması (2019) bunlardan bazılarıdır. Ancak literatürde kader olgusunun bireylerin zihinlerindeki izdüşümlerini fenomenolojik açıdan ele alıp inceleyen bir araştırmaya rastlanmamıştır. Bu nedenle araştırmanın konusu, kader algıları olarak belirlenmiştir. Fenomenolojik yaklaşımla gerçekleştirilen bu araştırmada metafor analizi yöntemiyle üniversite öğrencilerinin kader algılarını tespit etmek amaçlanmaktadır. Metafor analiziyle sadece kaderle ilgili öğretilmiş bilgilerin değil gerçek algıların zihinlerdeki sembolik yansımalarına ulaşılması beklenmektedir. Bu çerçevede araştırmada şu sorulara yanıt aranmaya çalışılmışıtır:

1. Araştırmaya katılan üniversite öğrencilerinin kader kavramına ilişkin geliştirdikleri metaforlar nelerdir? 
2. Üretilen metaforlar ortak özellikler bakımından hangi kavramsal kategoriler ve temalar altında toplanabilir?

3. Üniversite öğrencilerinin kader algısı nasıldır?

4. Üniversite öğrencilerinin kader algıları tamamen inanç temelli midir?

5. Üniversite öğrencileri arasında kader algısı fatalistik olan var mıdır?

\section{Kader ve Kaderle İlişkili Kavramlar}

Kader, Arapça bir sözcük olup kelime itibariyle "gücü yetmek; planlamak, ölçü ile yapmak, bir şeyin şeklini ve niteliğini belirlemek, miktarını/niceliğini açıklamak, kıymetini bilmek; rızkını daraltmak"1 gibi anlamlara gelmektedir. Kavramsal olarak ise farklı kader görüşlerine göre tanımları değişmektedir. Bir tanımda kader, insan iradesine hiç değinilmeyerek "Allah'ın bütün nesne ve olayları ezelî ilmiyle bilip belirlemesi, takdir etmesi ve bir şeye hükmetmesi”" olarak tarif edilirken bir başkasında insan iradesine vurgu yapılarak "İnsanın sorumlu ve özgür bir varlık olmasıdır." şeklinde tanımlanmaktadır. Kadere fatalistik anlamın verildiği tanımlar da bulunmaktadır. Türk Dil Kurumu sözlüğünde kader kavramına alın yazısı, yazgı, kaçınılmaz kötü talih gibi anlamlar verilirken alın yazısına inanan ve ondan yana olana kaderci; yazgıcılı̆̆a, Cebriyye'ye ve fatalizme kadercilik denmiştir. ${ }^{4}$

Kaderle ilişkili ve kader kavramının yerine kullanılan bazı kavramlar vardır. Bunlardan biri olan “yazgı" ya "bütün olmakta ve olacak olanların önceden ve değişmeyecek biçimde düzenlendiğine inanılan doğaüstü güç, alın yazısı, kader, mukadderat" ${ }^{5}$ anlamı verilmiştir. Kader kavramı yerine kullanılan "alın yazısı" kavramına verilen anlam da "yazgı"ya yakındır. Alın yazısı ise "yazgı, kader, talih, mukadderat" demektir. ${ }^{6}$ Bu kavram iyi veya kötü hangi durumda yaşarsa yaşasın insanın başına gelenlere katlanmasını ve olanları kabullenmesini anlatmak için insanın değiştirmeye gücünün yetmediği durumlarda yaygın bir şekilde kullanılmaktadır. ${ }^{7}$ Öte yanda halk dilinde kullanılan "felek" kavramı, dünya ve âlem anlamı yanında baht ve şans anlamlarıyla kaderle ilişkilendirilen kavramlardandır. Ancak kader bir dinî inanç konusu olduğundan insanlar olumsuz nitelendirmeler yapılan felek kavramını kader yerine kullanmaktan kaçınırlar. Zira felek bütün olumsuzlukların müsebbibi olan doğaüstü nedensellik kaynağıdır. ${ }^{8}$

Nasip, kısmet kavramları sıklıkla kaderle ilişkilendirilen kavramlardandır. Bunlardan nasip, “birinin payına düşen şey” iken kısmet, "Tanrı'nın her kişiye uygun gördüğü yaşama durumu"10

Ragıb el- İsfahani, Müfredat Elfazi'l Kur'an-Kur'an Kavramları Sözlüğü, çev. Yusuf Türker (İstanbul: Pınar Yayınları, 2012), "kdr”, 1182; Muhammed b. Mükerrem İbn Manzûr, Lisânü'l-‘'Arab, nşr. Abdullah Ali el-Kebîr (Kahire: Dârü'lMaârif, ts.), "kdr", 74.

Yusuf Şevki Yavuz, "Kader”, Türkiye Diyanet Vakfi İslam Ansiklopedisi (İstanbul: TDV Yayınları, 2001), 24/58.

Ahmet Akbulut, Sahabe Dönemi İktidar Kavgası-Alevi Sünni Ayrışmasının Arka Planı (Ankara: Otto Yayınları, 2017), 276.

Hasan Eren vd., Türkçe Sözlük (Ankara: Türk Tarih Kurumu Basımevi, 1988), “Kader”, 2/755.

Eren vd., "Yazg1", 2/1611.

Eren vd., "Alın Yazısı", 1/52.

Celaleddin Çelik, “Teodisenin Sosyolojisi”, Bilimname 2 (2007), 49.

Abdullah Özbolat - Saffet Kartopu, “İsyan ile Teslimiyet Arasında: Ağıtlarda Kader İnancı", Turkish Studies 7/3 (2012), 1963.

Eren vd., "Nasip", 2/1073.

Eren vd., "Kismet", 2/861. 
olarak tarif edilmektedir. Dinî literatürde yer alan "levh-i mahfuz" da kaderle ilişkili bir kavram olup yaşananların gelişi güzel değil ilâhî bir plan dâhilinde gerçekleştiğine dair inancın bir parçasıdır. Mahiyeti ancak Allah tarafından bilinebilecek kitap anlamına gelen "levh-i mahfuz"la ilgili âyetlerden anlaşıldığına göre kâinatta meydana gelecek her şey bu kitapta yazılıdır. ${ }^{11}$

\section{Fatalizm}

Kaderle ilişkili kavramlardan biri de fatalizm (kadercilik)'dir. Fatalizm, her şeyin sonucunun belli olduğunu, çaba harcayarak veya önceden harekete geçerek bu sonuçlardan kaçılamayacağını ve bu durumun sadece yaşamın kaçınılamaz bir olgusu olarak kabul edilmesi gerektiğini öngören bir inançlar sistemidir. ${ }^{12}$ Aynı zamanda bir felsefi görüş olarak da nitelendirilen fatalizm (kadercilik), Macit'e göre;

'Diğer kader algıları gibi hem geçmiş hem de gelecek için bir açıklama, tavır, tutum ve davranış önerisidir. O, geçmişi açıkladığı kadar geleceğe karşı takınılacak tavrı da belirlemektedir. Fatalizme göre gelecek, geçmişe benzer. Gelecek, insanın irade ve çabasına bakmaksızın hatta kimi zaman insanın irade ve çabasına rağmen önceden belirlendiği üzere gerçekleşecektir. Tıpkı geçmiş gibi onu değiştirmek adına, onu değiştirmek için hiçbir şey yapılamaz. Hiçbir insani neden onu değiştiremeyeceği için gelecek için adına takip edilecek tek rasyonel yol boyun eğmektir. ${ }^{13}$

Tarih boyunca dünyanın farklı yerlerinde ve farklı kültürlerde yaygın biçimde fatalistik eğilimin varlığı dikkat çekicidir. ${ }^{14}$ Örneğin Antikçağ Yunan inançlarında tanrıların bile kaderlerine bağlı olmaktan kendilerini kurtaramayacağı inancı bulunmaktadır. Tanrılar tanrısı Zeus'un söz geçiremeyeceği tek tanrıça kader tanrıçası Moira'dır. Çok eski tarihlere gidildiğinde dinden öte mitolojide de fatalizmin izlerini bulmak mümkündür. Kaderle ilgili inançlar hemen bütün mitolojilerde yer almıştır. ${ }^{15}$ Yunan edebiyatının en ünlü efsanelerinden biri olan ve Freud'un Oidipous Kompleksi Teorisine kaynaklık eden mitin kahramanı Oidipous ${ }^{16}$ henüz doğmadan bir kâhin, annesi Lokaste'ye karnındaki çocuğunun babasını öldüreceğini kendisiyle de evleneceğini söyler. Hikâye uzundur fakat dikkat çekici olan Oidipous'un kötü kaderinin gerçekleşmesinin önüne geçememiş olmasıdır. En sonunda Oidipous babası olduğunu bilmeden babasını öldürmüş, yine bilmeden annesiyle de ensest günahı işlemiştir. Böylece kehanet gerçekleşmiş, kaderin daha önceden belirlenmiş olduğu ve değiştirilemeyeceği inancı pekişmiştir. ${ }^{17}$ Diğer taraftan felsefede fatalizm, "alınyazısı öğretisi" olarak tartışılmış fakat çoğunlukla determinizm ile karıştııılmışır. ${ }^{18}$ Oysa evrendeki olayların zorunlu sebepler zincirine bağlı olarak gerçekleştiğini, bu sebeple insanda özgür irade olmadığını savunan deterministler, insanın çabalarından bağımsız her şeyi belirleyen güçler olduğunu savunan fatalizmin determinizmin bir türü olduğu iddialarına karşı

Yusuf Şevki Yavuz, "Levh-i Mahfuz", Türkiye Diyanet Vakfi İslam Ansiklopedisi (Ankara: TDV Yayınları, 2003), 27/151. Gordon Marshall, Sosyoloji Sözlüğü, çev. Osman Akınhay - Derya Kömürcü (Ankara: Bilim ve Sanat Yayınları, 2014), "Kadercilik", 373.

13 Mustafa Macit, Boyun Eğme-Başa Çıkma Sarkacında Kadercilik (İstanbul: Ötüken Neşriyat, 2014), 21.

14 Kamil Orhan, "Kadercilik Eğilimi Ölçeği'nin Geçerlik ve Güvenirlik Çalışması", Uluslararası Medeniyet Çalısmaları Dergisi 2/2 (2017), 87.

15 Hançerlioğlu, "Kadercilik", 289.

16 Ali Köse, Freud ve Din (İstanbul: İz Yayıncılık, 2005), 37-39.

17 Pierre Grimal, Mitoloji Sözlüğ̈̈- Yunan ve Roma, çev. Sevgi Tamgüç (ìstanbul: Kabalcı Yayınevi, 2007), 549-553.

18 Hançerlioğlu, “Kadercilik”, 289. 
çıkarlar. Onlar, determinizmin sonuçlarda insanın çabalamasını göz ardı etmediğini ileri sürerler. ${ }^{19}$

Dinî inançların fatalizmi ortaya çıkarma potansiyeli olmakla birlikte fatalist eğilimlerin yegâne kaynağı din değildir. Zira dinin dışında kişilik gibi bireysel faktörlerin, kültür gibi toplumsal faktörlerin ve toplumların yaşam deneyimlerine bağlı olarak ortaya çıkan yaygın anlayışların fatalizm eğilimini beslediği görülmektedir. ${ }^{20}$ Oysa fatalizmi insanı atalete, pasifliğe, istenmeyen boyun eğme davranışına götüren bir dinî inanç olarak değerlendirenlerin sayısı hiç de az değildir. Örneğin Hançerlioğlu fatalizmi (kadercilik), kader inancı ile aynı anlamda kullanmakta ve dinle ilişkilendirmektedir. Ona göre;

'Kader ya da kadercilik bütün olmakta ve olacak olanların doğaüstü bir güç tarafından önceden saptandığı ve değiştirilemeyeceği inancıdır. Tanrı bilimsel bütün felsefeler, Hristiyan ve İslam disiplinleri dâhil kadercidirler. Çünkü Tanrı inancı, ayrılmaz bir nitelik olarak, kaderi gerekli kılmaktadır. Tanrının sonsuz gücü inanıı, insanların özgürlüklerini yadsımayı gerektirir. ${ }^{21}$

İslam'da ise genel kabul gören görüş, fatalist anlayışın İslam'la uyuşmadığıdır. Bolay'a göre “Fatalistin evi yansa su dökmeyi lüzumsuz görür. İslam'da böyle bir anlayışa yer yoktur." Hatta ona göre fatalizme yakınlığı ile bilinen Cebriyyeciliği bile fatalizmle karıştırmamak gerekmektedir. ${ }^{22}$ Ülgener'e göre de kadercilik dinin hele de İslam'ın getirdiğgi bir şey değil; çöl ve bozkır adamının eğip bükemediği tabiat zoru karşısında aczinin ifadesidir. Ona göre bu zihniyet, teslimiyet adı ve maskesi ile İslam'a girmiş ve dinin desteği ile kutsallaştırılarak varlığını sürdürmüştür. ${ }^{23}$

\section{Kader Algısına Etki Eden Faktörler}

Kader denildiğinde ilk etapta akla dinî inanç geliyorsa da kadercilikten kadere imana uzanan çizgide farklı renklerin ve algı biçimlerinin olması, kader algısının oluşumunda tek kaynağın din olmadığını ortaya koymaktadır. Elbette dinî inançlar, kader algılarının oluşumunda güçlü bir etkiye sahiptir. Örneğin Müslüman toplumlarda İslam inancı, kader algılarının oluşumunda belirleyici faktörlerden biridir. ${ }^{24}$ Ancak bireylerin kader algıları sadece dinî inançlarından değil

19 Bolay, “Determinizm”, 46; Abdulbaki Güçlü vd., Felsefe Sözlüğü (Ankara: Bilim ve Sanat Yayınları, 2008), 190; İbrahim Coşkun, Günümüz Akaid ve Kelam Problemleri (İstanbul: Kitap Dünyası, 2017), 47.

Orhan, "Kadercilik Eğilimi Ölçeği'nin Geçerlik ve Güvenirlik Çalışması", 88.

Orhan Hançerlioğlu, İnanç Sözlüğü (İstanbul: Remzi Kitabevi, 1975), “Kadercilik”, 289-290.

Süleyman Hayri Bolay, Felsefi Doktrinler Sözlüğü (Ankara: Akçağ Yayınları, 1987), "Fatalizm”, 88.

Sabri Ülgener, Zihniyet ve Din-İlam, Tasavvufve Çözülme Devri İktisat Ahlakı (İstanbul: Der Yayınları, 1981), 15.

İslam'da amentü esasları arasında yer alan kadere Müslümanların çoğu şüphe duymaksızın iman etmektedir. Ancak Kur'an'da kader konusunun Allah-kâinat ve Allah-insan ilişkisi bağlamında yer alması ve kadere imanın doğrudan doğruya imanın şartları arasında sayılmaması, kadere inanmanın imanın şartlarından olup olmadığı konusunu tartışmalı hale getirmiştir (Kur'an-1 Kerim Meali, çev. Halil Altuntaş - Muzaffer Şahin (Ankara: Diyanet İşleri Başkanlığı Yayınları, 2009), el-Bakara 2/177; en-Nisâ 4/136; Hüseyin Atay, Kur'an'da İman Esasları ve Kader Sorunu (Ankara: Atay Yayınları, 2013), 123-124). Hadislere bakıldığında ise bazı rivâyetlerde kaderin imanın şartları arasında sayılmadığı (Hadislerle İslam, ed. Mehmet Emin Özafşar vd. (Ankara: Diyanet İşleri Başkanlığı Yayınları, 2013), 1/529), bazı rivâyetlerde ise hayrın ve şerrin Allah'tan geldiğine inanma ve kadere inanmanın birlikte iman esasları arasında yer aldığı görülmektedir (Hadislerle İslam, ed. Mehmet Emin Özafşar vd. (Ankara: Diyanet İşleri Başkanlığı Yayınları, 2013), 1/587). Kader inancı ile ilişkili olarak İslam düşünce tarihinde itikâdî alanda "Cebriyye, Mu'tezile, Eş‘ariyye, Mâtürîdiyye” mezheplerinin farklı görüşlerinin olduğu bilinmektedir. Bu farklı görüşler, bu 
yaşadıkları çevreden, aldıkları eğitimden, yetiştirildikleri aileden, kendi kişilik özelliklerinden ve daha birçok faktörden etkilenerek şekillenmektedir.

Kader algısının oluşumuna etki eden, bireylerin kader karşısındaki tutumlarının belirlenmesinde etkili olan faktörlerden biri kültürdür. Belli bir kültürün ürünü olan deyimler, atasözleri, ağıtlar, türküler vs. kültürel anlamda önemli referanslardır. ${ }^{25}$ Halk kültüründe yer alan kader konusundaki bu referanslar, bireylerin algılarını örtük biçimde şekillendirmektedir. Bununla birlikte Doğu-Batı kültürlerinin karakteristik özelliklerinin o toplumlarda yaşayan bireylerin kader algılarına yansıdığı belirtilmektedir. Bu bağlamda kolektivist Doğu toplumlarının itaatkâr ve kabullenici bir kişiliğe yol açtığı, bu toplumlarda dışsal nedensel açıklamalara Batı kültüründen daha fazla rağbet edildiği, bunun da fatalizm eğilimini beslediği ileri sürülmektedir. ${ }^{26}$ Diğer taraftan fatalistik eğilimlerin düşük sosyoekonomik düzeye sahip dezavantajlı gruplarda yaşayan bireyler tarafından daha fazla tercih edildiği görüşü, yaygın görüşlerden biridir. Fakat her iki iddiayı da doğrulayacak yeterince kanıt bulunmamaktadır. Batı kültürünün kökenini oluşturan Antik Yunan geleneğinde fatalizmin köklerinin bulunması, bu eğiliminin Doğu toplumlarına mahsus olmayıp Batı toplumlarında da yaygın olduğunun işaretidir. ${ }^{27}$ Fatalistik inancın toplumların kalkınması ve ilerlemesinin önünde bir engel olduğu sosyologlarca dile getirilmektedir. ${ }^{28}$ Eğer fatalizm sosyopsikolojik bir problem olarak görülüyorsa, bunu insanlığın temel problemlerinden biri olarak değerlendirmek daha objektif bir yaklaşım olur. Zira hemen her kültürde fatalizmin izlerine rastlamak mümkündür. Fatalizmi genellemelerden uzak bir yaklaşımla Batı ya da Doğu kültürüne mahsus bir durum olmaktan çok evrensel nitelikli negatif bir olgu alarak görmek, gerçeğe daha yakın durmaktadır. Aksi takdirde fatalizmin ve bundan

mezhepleri benimseyenlerin kader görüşlerine dolayısıyla hayat perspektiflerine yansımaktadır. Bu bağlamda kader konusunda Cebri kader algısına sahip olan bireyler, insanın iradesini kabul etmeyerek eylemlerinde özgür olmadığını düşünürken bu fikirlere karşı çıkan Mu'tezili algıya sahip olanlar insanın özgür irade sahibi olduğunu, fiillerini kendisinin yarattığını ve dolayısıyla eylemlerinden sorumlu olduğunu kabul etmektedir. Mu'tezile'ye göre insan kudret sahibidir ve onun bu kudreti fiilden önce bulunmaktadır (ibrahim Coşkun, "Matürîdî Düşüncede Allahİnsan İlişkisi", Hikmet Yurdu 2/4 (2009), 26). Ehl-i Sünnet itikâdını temsil eden "Eş‘ariyye" mezhebini benimseyen bireyler ise "cüẑ̂̀ irâde" kavramılla insanın sorumluluğunu kısmen temellendiren görüşü kabul ederler. Çünkü Eş'ari'ye göre mutlak irade sahibi Allah'tır ve eylemden önce insanda irade ve kudret yoktur. "Kesb"ile ilgili olarak insanın eylem sırasında Allah’ın kendisine verdiği irade ve kudretle eylemi gerçekleştirdiğini savunan Eş‘ari, böylece insanın sorumluluğunu temellendirmeye çalışır (Coşkun, "Matürîdî Düşüncede Allah-İnsan İlişkisi”, 30). "Mâtürîdîyye" mezhebini kabul eden bireyler, "cüzî irâde"nin yanı sıra rasyonelleştirilmiş "Kesb-Kazanma" nazariyesini benimsemektedir. Mâtürîlîler Allah'ın insanı irade etme potansiyeli ile yarattığına, iradenin cüz'ileştirilmesinde Allah'ın müdahil olmadığına, farklı seçenekler karşısında insanın özgürce seçim yapabildiğine inanmaktadırlar. Onlara göre bu özgür seçimden sorumluluk doğmaktadır (Coşkun, "Matürîdî Düşüncede Allahİnsan İlişkisi”, 38-44; Bolay, "Fatalizm”, 87; İsmail Bulut, “Kader-Engellilik İlişkisine Kelami Bir Yaklaşım”, Atatürk Üniversitesi İlahiyat Fakültesi Dergisi 43 (2015), 26; Cengiz, "Emeviler Döneminde Kader Problemi", 107; Zeynep Özcan, “Yükleme, Kaygı ve Başa Çıkma Bağlamında Covid-19 Salgınına Dinî Bakış”, Dindarlık, Kişilik ve Ruh Sağ lı̆̆ı, ed. Nevzat Gencer - Muammer Cengil (İstanbul: Çamlıca Yayınları, 2020), 259-261).

25 Macit, Boyun Eğme-Başa Çıkma Sarkacında Kadercilik, 110.

26 Macit, Boyun Eğme-Başa Çıma Sarkacında Kadercilik, 33.

27 Orhan, “Kadercilik Eğilimi Ölçeği'nin Geçerlik ve Güvenirlik Çalışması”, 87; Macit, Boyun Eğme-Başa Çıkma Sarkacında Kadercilik, 35.

28 Çelik, “Teodisenin Sosyolojisi”, 57. 
kaynaklanan pasiflik ve kabullenici olmak gibi özelliklerin Doğu kültürlerine has olduğunu iddia etmek, ${ }^{29}$ indirgemeci bir yaklaşım olur.

Kader algılarının oluşumuna etki eden önemli etkenlerden biri de sosyokültürel faktörlerdir. Hayatın ilk yıllarında gerçekleşen kültürel aktarım, bireyin yükleme tarzlarının ortaya çıkmasına ve şekillenmesine etki ettiği gibi kader algısının oluşumuna ve nedensel açıklamalarda kullanılmasına da etki etmektedir. ${ }^{30} \mathrm{Bu}$ bağlamda ebeveyn tutumları, kader algılarını etkileyen sosyal faktörlerden biridir. Ebeveynler bebeklik döneminde ilk bilişsel şemaların oluşmasından itibaren farklı kader algıların benimsenmesine zemin hazırlayan davranışlar içerisinde olabilirler. Örneğin otoriter bir aile, çocuğunun davranışlarının toplum kurallarına uygun olmasını istediği için itaati bir değer olarak çocuğuna benimsetebilir. Demokratik bir aile ise itaat yerine özerk olmayı, bağımsızlığı, bireysel özgürlüğü değer olarak gören bireyler yetiştirebilir. Kişilik olarak birincisinde yetişen çocuklar dışsal kontrol odağına sahip olup kaderci tutumu benimserken, ikincisinde yetişenler içsel kontrol odağına sahip olup yaşam sorumluluğunu üstlenmeye istekli olabilirler. ${ }^{31}$ Ayrıca kader algısı her ne kadar dinî inançların yanı sıra kişiliğin ve sosyokültürel çevrenin etkisiyle biçimlense de bu algı sabit kalmayıp alınan eğitimin yanı sıra edinilen çeşitli yaşam tecrübelerinin etkisiyle pozitif ya da negatif yönde değişim gösterebilmektedir.

Bireylerin kader algıları günlük sosyal etkileşim vasıtasıyla kazanılan öğrenilmiş yorumlardan etkilendiği gibi ${ }^{32}$ almış oldukları eğitimden de etkilenmektedir. Ülkemizde zorunlu din eğitimi derslerinde kader konusu iman esasları arasında öğretilmektedir. Keskiner, okullarda okutulan Din Kültürü ve Ahlak Bilgisi ders kitaplarını kader öğretisi açısından incelemiş, kitaplarda kaderle ilgili doğru bir algının kazandırılıp yanlış algının düzeltilmesine ilişkin bir yaklaşımın esas alındığını tespit etmiştir. Ayrıca değerlendirmesinde bu konuda önceden oluşmuş yerleşik yargıları yıkmanın kolay olmadığını ve öğretmen faktörünün önemli olduğunu belirtmiştir. ${ }^{33}$ Başta dinler olmak üzere felsefeden edebiyata pek çok alanın ortak problemlerinden olan kaderle ilgili görüş ayrılıkları o kadar derindir ki insanların üzerinde uzlaşacağı bir çözümle kaderi açıklamak imkânsız görünmektedir. ${ }^{34}$ Hal böyle olunca kader konusunu gençlere öğretirken kullanılan dilin önemi kendiliğinden ortaya çıkmaktadır. Okul çağındaki gençlerin sorgulayıcı kimlikleri düşünüldüğünde gençlere kader konusunda çelişkili açıklamalar yapma, doğru kader algısı kazandıramama gibi durumlarda konunun dinî sorgulamalara temel teşkil edebileceği söylenebilir. Zira özellikle ergenlik dönemindeki gençlerin en fazla kader, insanın özgürlüğü gibi konularda dinî şüphe yaşadıklarını araştırmalar göstermektedir. ${ }^{35}$

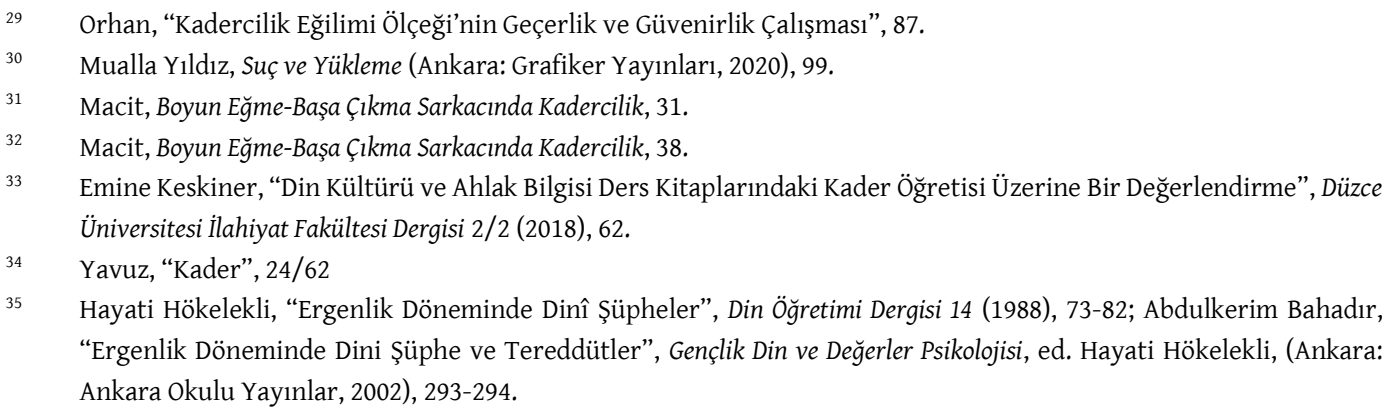


Kader karşısındaki tutumların ortaya çıkmasında belirleyici faktörlerden biri de kişilik özellikleridir. Bu konuda "içsel kontrol odağı ya da dışsal kontrol odağı" kişilik özelliği üzerinde durulmaktadır. İçsel kontrol odağı, bireyin kendi davranışları ve davranışlarının sonuçları üzerinde kontrol sahibi olduğuna inandığ kişilik eğilimi iken dışsal kontrol odağı tam tersine bireyin kontrol gücüne sahip olmadığına, hayatının ve yaşadığı olayların şanssızlık, başkaları, kader gibi kendi dışındaki etkenlere bağlı olduğuna inandığı kişilik yönelimidir. ${ }^{36}$ Buna göre içsel kontrol odağına sahip bireyler kader karşısında sorumluluk yüklenen tiplerken dışsal kontrol odağına sahip olanlar ne yaparlarsa yapsınlar kaderlerini değiştiremeyeceklerini düşünenler olabilirler.

\section{Psikolojik Perspektiften Kader İnanc1 ve Fatalizm (Kadercilik)}

Psikolojik bir olgu olarak bireylerin kader algıları, ister dinî inanca isterse dinden bağımsız nedenlere dayansın onların davranışlarını etkilemekte, hep aynı şekilde davranma eğilimi oluşturabilmektedir. Bu yönüyle kadere ilişkin algılar birer tutum olarak değerlendirilebilir. Diğer tutumlar gibi kadere ilişkin tutumların bilişsel, duygusal ve davranışsal olmak üzere üç öğesi bulunmaktadır. ${ }^{37}$ Örneğin inanç temelli kader tutumunda duygusal öğeyi imanın en temel duygusu güven oluşturabilirken fatalizmde umutsuzluk, çaresizlik duyguları oluşturabilir. Bilişsel boyutta ise inanç temelli kader tutumunda yaşananlar Allah'ın ilim, kudret, irade gibi sıfatlarına ve her şeyin ilâhî kontrol altında olduğu düşüncesine dayandırılabilirken fatalizmde bilinmeyen güçler tarafından yaşanacakların önceden belirlendiği, ne yapılırsa yapılsın sonucun değişmeyeceği düşüncesi hâkim olabilir. Davranışsal boyutta inanç temelli kader tutumunda insanın eylemlerinde özgür olduğu düşünülüyorsa sabırla sürdürülen aktif bir mücadelenin ardından Allah'a tevekkül; düşünülmüyorsa doğrudan Allah'a havale ve teslimiyet davranışı görülebilir. Fatalist tutumda ise yüce bir güce değil, başa gelenlere çaresizce boyun eğme ve pasifleşme görülebilir.

Kader inancı ile fatalizm (kadercilik) arasında hem kavramsal anlamda hem de psikolojik işleyiş bakımından farklılıklar bulunmaktadır. Her ikisinde de yaşanacakların önceden belirlenmiş olduğu inancı olmakla birlikte kader inancında; her şeye hâkim, kontrol eden, idare eden Yüce kudrete ve insan özgürlüğüne atıf yapılırken fatalizmde genellikle metafizik bir varlığa değil şans, baht gibi belirsiz olgulara atıf yapılmaktadır. Kader inancında psikolojik olarak pozitif süreçler yaşanırken fatalizmde negatif süreçler yaşanmaktadır. Her ikisinde de kabullenici bir tutum görülmekle birlikte kader inancında bu kabullenme Allah'a olan inanç ve güvenin etkisiyle sabır, şükür, tevekkül, rıza gibi psikolojik iyi oluşu destekleyen hallerin yaşanmasına zemin hazırlarken fatalizmde umutsuzluk, öğrenilmiş çaresizlik gibi ruhsal sorunları tetikleyen hallerin yaşanmasına yol açabilmektedir.

36 Martin B. Kormanik, Tonette S. Rocco, "Internal Versus External Control of Reinforcement: A Review of the Locus of Control Construct”, Human Resource Development Review 8/4 (2009), 466; İhsan Dağ, Kontrol Odağ1, Stresle Başa Çıkma Stratejileri ve Psikolojik Belirti Gösterme İlişkileri (Ankara: Hacettepe Üniversitesi, Sosyal Bilimler Enstitüsü, Doktora Tezi, 1990), 4-5 ; Selçuk Budak, Psikoloji Sözlüğü (Ankara: Bilim ve Sanat Yayınları, 2017), "İçsel Kontrol Odağı", 202; Budak, "Dişsal Kontrol Odağı", 369.

37 Çiğdem Kağıtçıbaşı, İnsan ve İnsanlar (İstanbul: Evrim Matbaası, 1996), 86. 


\subsection{Atıf/Yükleme ve Kader Algısı}

Kader konusunun psikoloji alanında en ilişkili olduğu kuramın atıf/yükleme teorisi olduğu söylenebilir. Zira psikolojide atıf/yükleme (attribution) bireyin kendi davranışları da dâhil olmak üzere, olayların nedeni konusundaki çıkarımları ve yaşananların nedenlerine ilişkin açıklamaları olarak tarif edilmektedir. ${ }^{38}$ Her bireyin tercih ettiği bir "yükleme tarzı" bulunmakta, bu yükleme biçimi bireyin hayata bakışını, hayat karşısında takındığı tavrı göstermektedir. ${ }^{39}$ Araştırmacılar insanların olayları devam edip giden bir düzene atfetme eğiliminde olduklarını tespit etmişlerdir ki kader bunlardan biridir. ${ }^{40} \mathrm{Bu}$ bağlamda bir nedensel açıklama aracı olarak kaderin, çoğu bireyin atıf sisteminde yer aldığı söylenebilir.

İnsanların yaşanan olumsuzlukları açıklama ve yükleme eğiliminin olumlulara oranla daha fazla olduğu belirtilmektedir. Buna göre birey yaşadığı başarısızlığı nedensel olarak açıklamaya, elde ettiği başarının nedenini açıklamaya oranla daha çok ihtiyaç hissetmektedir. Başarısızlık ve trajik yaşantılar gibi özsaygı duygusunda olumsuz değişiklikler yapan durumlar karşısında bireyler nedensel açılamalar yapmaya ve özsaygıyı onarmak için atıf sürecine girmeye daha eğilimlidirler. ${ }^{41}$ Zira her türden olumsuzluk ve başarısızlık potansiyel olarak bireyin benlik saygısını tehdit etmektedir. Atıf/yükleme ya da nedensel açıklamalar, adeta yaşananların bireyin benliğinde yaptığı tahribatı onarma amacı taşımaktadır. Literatürde atıf yapmaya götüren üç temel ihtiyaçtan söz edilmektedir. Bunlar anlam arama, sonuçları kontrol altına alma ve özsaygı ihtiyacıdır. Atıf biçimini belirleyen faktörler ise atfedenin özellikleri, atfedenin içinde bulunduğu durum, olayın özellikleri ve olayın geçtiği yer ve ortam olarak sıralanmaktadır. ${ }^{42}$

Din anlam kaynağııın temelidir. Kader inancı yaşananları anlamlandırmada oldukça işlevseldir. Fatalizm (kadercilik) de anlamlandırmaya kaynaklık edebilir ancak yazgının değiştirilemez olduğu inancı öğrenilmiş çaresizliğe yol açabilir. Kader inancında ise anlamlandırma Allah inancı ve ahiret inancı ile birlikte daha işlevsel ve tatmin edici olmaktadır. Spilka ve arkadaşlarına göre yaşanan olayın trajik olduğu durumlarda dinin sağladığı kalıp cümlelerden "Tanrı yapabileceğimiz şeyi bizden ister (taşıyamayacağımız yükü yüklemez)" düşüncesi sabrı artırırken "Tanrı bana iyi bir ders verdi" tatmin edici pozitif bir sonuç üretir, "Tanrı'nın planı" olayların Yüce gücün kontrolünde olduğu düşüncesi güven ve rahatlık verir. ${ }^{43}$

Yüklemenin amaçlarından biri olan kontrol sağlama konusunda kader inancında bireyin kader algısı, üzerine düşenleri yapması halinde istenen sonuçlara ulaşabileceği düşüncesine dayanıyorsa işlevsel olabilirken, ne yaparsa yapsın sonucu değiştiremeyeceği düşüncesine dayanıyor veya fatalizmde olduğu gibi kaynağı belirsiz dışsal faktörlerin kaderini belirlediğini

$38 \quad$ Fritz Heider, The Psychology of Interpersonal Relationship (New York: Jhon Willey and Sons, 1958), 169.

39 Budak, "Yükleme Tarzı", 816.

40 Bernard Spilka vd., "Din Psikolojisi Açısından Genel Bir Atıf Teorisi”, çev. Ali Kuşat, Journal for the Scientific Study of Religion 24/1 (1985), 175.

${ }_{41} \quad$ Spilka vd., "Din Psikolojisi Açısından Genel Bir Atıf Teorisi”, 178.

42 Spilka vd., "Din Psikolojisi Açısından Genel Bir Atıf Teorisi”, 173; İbrahim Gürses, "Yükleme Teorisi ve Din İlişkisi Üzerine Bir Değerlendirme”, Uludağ Üniversitesi İlahiyat Fakültesi Dergisi 17/2 (2008), 364.

${ }_{43}$ Spilka vd., "Din Psikolojisi Açısından Genel Bir Atıf Teorisi”, 180; Recep Yaparel, "Depresyon ve Dinî İnançlar ile Tabiatüstü Nedensel Yüklemeler Arasındaki İlişkiler”, Dokuz Eylül Üniversitesi İlahiyat Fakültesi Dergisi 8 (1994), 278. 
düşünüyorsa olumlu bir işlev görmeyebilir. Ancak birey kader inancında da fatalizmde de nedensel açıklamaları kendisinin dışındaki bir faktöre yüklediği için her ikisinin de özsaygıyı koruma, sürdürme ve yüceltme konusunda işlevsel oldukları söylenebilir.

Atıf yapılırken yaşam görüşü ve anlamlandırma-inanç sistemleri bireyin atıf tarzını belirlediğinden yapılan yüklemelerin dinî veya din dışı olması, bireyin atıf tarzı ile ilişkilidir. Dindarlık bireyin kişiliğinin bir parçasıdır ve hayatında dine önem veren bireylerin dinî yüklemeler yapmaya daha eğilimli oldukları söylenebilir. Zira din, yükleme konusunda önemli bir kaynağı oluşturmaktadır. Yaşananlara nedensel açıklamalar yapmak gerektiğinde dinî yüklemeler; kontrol duygusunun sağlanması, anlamlandırma ve özsaygı ihtiyacını karşılamaya yardımcı olmaktadır. Dinî yüklemeyi tercih eden birey Tanrı'nın evreni yöneten sonsuz gücünü kendi yanında hissedebilmekte, Tanrı tarafından onaylandığı hissini yaşayabilmekte ve böylece kaybettiği kontrol duygusunu ve öz saygıyı yeniden kazanabilmektedir. Din dışı yüklemelere göre dinî yüklemeler, yaşananları daha tatmin edici bir şekilde anlamlandırmayı sağlamaktadır. ${ }^{44} \mathrm{Bu}$ tür anlamlandırmalar bireylerin yaşadığı zorluklarla başa çıkmalarına ve duygusal ve zihinsel dengelerini yeniden kurmalarına yardımcı olmaktadır..$^{45}$

İçsel ya da dışsal kontrol odağına sahip olmak bir kişilik özelliği olarak kadere atıf yapma eğilimini belirleyen faktörlerdendir. Ayrıca atıf/yükleme yapmayı gerektiren olayın özellikleri, nedensel açıklamaların biçimini ve içeriğini belirlemektedir. Beklenmedik anda ortaya çıkan ve bireyin dünyaya ilişkin varsayımlarını alt üst eden travmatik yaşam olayları sırasında kader eksenli nedensel açıklamalara daha sık başvurulmaktadır. Bireyin tercihlerinin sonuç üzerinde bir etkisinin olmadığı bu gibi olaylar rasyonel açıklamalara imkân vermediğinden, dinin güvenli liman olma fonksiyonu devreye girmekte, bilişi yaşananlarla ilgili içinden çıkılması mümkün olmayan sorgulamalara kapatmakta ve kader inancının sağladığı teslimiyet duygusu bireyi bir taraftan rahatlatırken diğer taraftan adeta iman koruma altına alınmaktadır. ${ }^{46}$

Yapılan araştırmalar dindar insanların Tanrı'nın kontrolüne dindar olmayanlara göre daha fazla atıfta bulunduklarını göstermektedir. Ancak yaşanan hadise bir felaketten kurtulma gibi olumlu bir sonuç içerdiğinde Tanrı'ya atıfta bulunma oranı yükselirken ölüm gibi bir sonucu içerdiğinde düşmektedir. ${ }^{47}$ Örneğin Gorsuch ve Smith'in çeşitli fakültelerden üniversite öğrencileri ile gerçekleştirdikleri bir araştırmada katılımcıların dinî tutumları ile olayların nedensel açıklamalarını yaparken Tanrı'ya yaptıkları atıflar arasında ilişki olduğu belirlenmiştir. Elde edilen bulgular, kökten dinci olanların olmayanlara göre; Tanrıya kendini çok yakın hissedenlerin hissetmeyenlere göre Tanrı'ya daha fazla sorumluluk yüklediklerini, şansa daha az yükleme yaptıklarını göstermiştir. ${ }^{48}$ Bir kaza sonucu yarı felçli ya da kısmi felçli kalan bireylerle yapılan mülakatta kazazedeler kaderlerinin Allah tarafında idare edildiğine inandıklarını

\footnotetext{
Gürses, "Yükleme Teorisi ve Din İlişkisi Üzerine Bir Değerlendirme”, 372.

45 Asım Yapıcı, “Kovid-19 Küresel Salgınına Dinî ve Din Dışı Yüklemeler, Tanrı'nın Gazabı mı? İnsanın Suçu mu?", Küresel Salgınlara Farklı Bakışlar, ed. Ejder Okumuş (Ankara: Eski Yeni Yayınları, 2020), 126.

46 Faruk Karaca, Din Psikolojisi (Trabzon: Eser Ofset, 2017), 135.

47 Yıldız, Suç ve Yükleme, 65.

48 Richard Gorsuch - Craig S. Smith, "Attributions of Responsibility to God: An Interaction of Religious Beliefs and Outcomes”, Journal for the Scientific Study of Religion 22/4 (1983), 345.
} 
belirtmişlerdir. ${ }^{49} \mathrm{Bu}$ gibi durumlarda kader inancına dayalı nedensel açıklamalar rasyonel açıklamalar olmasa da sonucu kabullenmeyi kolaylaştırabilmektedir..$^{50}$ Ayrıca olayın dayanılabilir olup olmaması (sabır), olayın olumsuz sonuçlarıyla birlikte olumlu sonuçlarını tespit etme (her şerde bir hayır vardır, şükür), olayın rastlantı olmadığını bir planın parçası olduğunu kabul etme (yaşananlar Allah'ın kontrolündedir ve onun takdirine bağlıdır, kader planının bir parçasıdır, ben kontrol edemiyorum belki ama olayın kontrolü güvendiğim Yüce varlı̆̆ın elindedir, tevekkül, teslimiyet ve rıza) beklenmedik veya travmatik yaşantılarda bozulan anlam-inanç sistemlerini onarmaya yardımcı olmaktadır. ${ }^{51}$ Dinî yüklemeler yapılırken Tanrı'nın merhametine, adaletine, olayları önceden biliyor ve yönetiyor olmasına sıklıkla atıfta bulunulmaktadır. ${ }^{52}$ Ancak yaşananların bir tesadüf olmadığı, ilâhî planın parçası olduğu düşüncesi kabullenmeyi kolaylaştırdığından kader inancının atıf sürecine etkisinin pozitif olması beklenirken fatalizmde olaylar şans ve tesadüfe bağlandığından böyle bir etki beklenmemektedir.

\subsection{Savunma Mekanizmaları ve Kader Algisı}

Psikolojide savunma mekanizmaları "bireyi kaygıdan, suçluluk duygularından, bilinçsiz içsel çatışmalardan, bastırılan kabul edilemez bilinçdışı dürtülerden ve egonun karşı karşıya gelebileceği diğer tehditlerden koruyan ve genellikle bilinçsiz olan otomatik savunma tepkileri" şeklinde tanımlanmaktadır. ìlk kez Freud tarafından ortaya konan, küçük kızı Anna Freud tarafından geliştirilen savunma mekanizmaları, birey açısından sağlıklı bir uyum tepkisi olabileceği gibi aşırıya kaçılması halinde patolojik olabilmektedir. ${ }^{53}$

Kader olgusunun bireyi suçluluk duygusunun baskısından kurtaran bir savunma mekanizması işlevi gördüğü belirtilmektedir. Kişisel yetersizlik nedeniyle amaçlarını gerçekleștiremeyen ve başarısızlık yaşayan bireylerin benliği ve kişisel değer duygusu zedelendiğinde, kendisini mazur gösterme ihtiyacı doğabilir. Burada birey kaderi, mantığa bürüme savunma mekanizması olarak kullanabilir. Ayrıca birey, toplumun onaylamadığı ve kendisini küçük düşüren davranışlarının nedenlerini kendisi dışındaki kişi veya duruma bağlayarak vicdanını rahatlatmaya çalışabilir. Burada da kaderi yansıtma savunma mekanizması olarak kullanabilir. ${ }^{54}$ Fakat kaderin savunma mekanizması olarak kullanılmasının inanç temelli kader algısından çok fatalizme (kadercilik) uygun düştüğü söylenebilir. Çünkü kader inanc1, nedensel bir açıklama aracı olarak kullanıldığında ve dinsel anlamlandırmanın bir parçası olduğunda, birey rasyonel olmasa bile bilinçli gerekçeler üretmeye çalışmaktadır. Bu bağlamda aşırı hız nedeniyle trafik kazası yapıp ölüme sebebiyet veren bir sürücünün ölen kişi için "ömrü o kadarmış demek ki, kader işte" demesi, savunma mekanizması olabileceği gibi bu açıklaması "ömrün sınırlı olduğu ve süresinin belirlenmiş olduğu" gibi bir dinî inançla irtibatlı olabilir. Ancak eğer birey kendisini zor durumda bırakan her olayı kadere atıf yaparak çözümlemeye çalışıyorsa ve bunu da otomatik bir tepkiye dönüştürmüssse, yansıtma veya mantığa büründürme gibi bir savunma mekanizmasını kullandığı

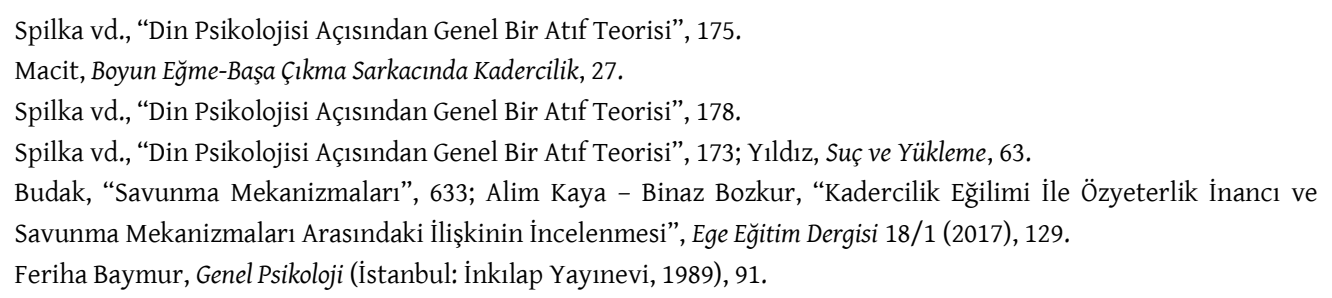


söylenebilir ki bu durumda fatalistik eğilim etkili faktör olabilir. Kadere yazgı anlamı yüklemek, bir savunma mekanizması olarak kullanıldığının göstergesi olabilir. ${ }^{55}$ Zira kader savunma mekanizması olarak kullanıldığında kutsal varlıkla ilişki ya yoktur ya da çok zayıftır. ${ }^{56}$ Cezaevi mahkumlarına "kader mahkumları" denmesi, kaderin savunma mekanizması olarak kullanılabildiğini gösteren örneklerdendir. Zira suçlu ne yaparsa yapsın o olay yaşanacaktı düşüncesiyle kadere atıf yapmak, suçluluk duygusunun suçlunun vicdanında oluşturduğu rahatsızlığı hafifletebilir. Ancak kaderi savunma mekanizması olarak kullanmak her ne kadar stresi hafifletici, vicdanı rahatlatıcı, teselli edici etki yapsa da etkili bir problem çözme yöntemi olmayacaktır.

\subsection{Kontrol Odağı ve Kader Algısı}

Farklı kader tutumları psikolojide kontrol odağı çalışmalarına konu olmuştur. ${ }^{57}$ Rotter'in davranış kontrolünde sorumluluğun merkezini anlatmak için kullandığ kontrol odağ kavramı, bireyin yaşadığı olayların sorumluluğunu kendi içindeki veya dışındaki etkenlere yükleme eğilimiyle tanımlanan bir kişilik özelliğidir. ${ }^{58}$ Bireyin kader algısı yaşananlara müdahale yetkisinin olmadığı düşüncesine dayanıyor ve birey olanlardan kendisini sorumlu tutmuyorsa kişilik olarak dışsal kontrol odağına sahip olabilir. Yapılan araştırmalarda dışsal kontrol odağına sahip olmakla fatalistik eğilim arasında pozitif yönlü ilişkiler tespit edilmiştir. Bu eğilimin pasiflik, önlem alınması gereken durumlarda önlem almayıp risk alma gibi olumsuz davranış örüntüleriyle ilişkili olduğu düşünülmektedir..$^{59}$ Bu bağlamda İslam'ın kaderle ilgili yorumlarından cebrî kader yaklaşımını destekleyenlerin de dışsal kontrol odağına sahip olabilecekleri söylenebilir. Zira bu anlayışa göre insanın ne iradesi vardır ne de yaptıklarından sorumludur. ${ }^{60}$ Bununla birlikte tek başına cebri kader algısına sahip olmak, dışsal kontrol odağını bütünüyle açılayan bir faktör olamaz.

\subsection{Başa Çıkma ve Kader Algısı}

Başa çıkma, bireyin kaynaklarını aşan veya bireyi yıpratan, iyilik halini tehlikeye sokan, kapasitesini azaltıcı ve zorlayıcı olarak değerlendirilen iç ve dış özel durumlarla mücadele etmek için sürekli değişen bilişsel ve davranışsal çabalar olarak tanımlanmaktadır. ${ }^{61}$ Başa çıkmanın problem odaklı ve duygu odaklı olmak üzere iki türü bulunmaktadır. Problem odaklı başa çıkma, aktif bir süreç olup problemi tanımlama, alternatif çözümler üretme, bir çözümü seçme, çözümü

55 Cüneyd Aydın, "Kader İnancının Savunma Mekanizması ve Dinî Başa Çıkma Kavramları Açısından Değerlendirilmesi”, Hitit Üniversitesi İlahiyat Fakültesi Dergisi 18/35 (2019), 112-113; Yıldız, Suç ve Yükleme, 174.

56 Aydın, “Kader İnancının Savunma Mekanizması ve Dinî Başa Çıkma Kavramları Açısından Değerlendirilmesi”, 111; Yıldız, Suçve Yükleme, 84.

57 İhsan Dağ, “Kontrol Odağı Ölçeği (KOÖ): Ölçek Geliştirme, Güvenirlik ve Geçerlik Çalışması.”, Türk Psikoloji Dergisi 17/49 (2002), 85.

$58 \quad$ Noel Sheehy vd., Biographical Dictionary of Psychology (New York: Routledge, 2002), “Julian Rotter”, 492; Dağ, Kontrol Odağı, Stresle Başa Çıkma Stratejileri ve Psikolojik Belirti Gösterme İlişkileri, 4-5; Budak, "Kontrol Odağı”, 449.

59 Alim Kaya - Binaz Bozkur, "Kadercilik Eğilimi Ölçeğinin Geliştirilmesi: Geçerlik ve Güvenirlik Çalışması”, Mersin Üniversitesi Eğitim Fakültesi Dergisi 11/3 (2015), 937.

60 Faruk Karaca, “Kader Algısı -Ruh Sağlığı İlişkisi Üzerine Empirik Bir Araştırma”, İslamî Araştırmalar Dergisi 19/3 (2006), 480.

61 Richard S. Lazarus - Susan Folkman, Stress, Appraisal and Coping (New York: Springer Publishing Company, 1984), 141; Mebrure Doğan, Sabır Psikolojisi- Pozitif Psikoloji Bağlamında Bir Araştırma (İstanbul: Çamlıca Yayınları, 2016), 153. 
uygulama ve problem çözülemediyse yeniden değerlendirme gibi aşamalardan oluşmaktadır. ${ }^{62}$ Duygu odaklı başa çıkma ise özellikle durum değiştirilemeyecek olduğunda stres yaratan olumsuz duygularla mücadele etmek ve yoğun duyguların baskısını hafifletmeye çalışmaktır. ${ }^{63}$ Kader inancı problem odaklı veya duygu odaklı başa çıkmanın enstrümanı olabilir. İnanç temelli kader algısına sahip olan birey, insan iradesini kabul ediyor ve durum aktif bir biçimde problem çözmeyi gerektiriyorsa, problem odaklı başa çıkmayı kullanabilir. Ancak bireyin kader algısı cebrî veya kaderci/fatalistik ise duygu odaklı başa çıkmayı daha fazla tercih edebilir. Duygu odaklı başa çıkmanın etkili olabilmesi, bireyin umutlu ve iyimser olmasına bağlıdır. Fatalizm çoğunlukla umudu tükettiğinden bu tür başa çıkma kısa süreli rahatlama sağlayabilir fakat problem etkili bir biçimde çözümlenmeyebilir. ${ }^{64}$

Din başa çıkmaya yardımcı olmakla birlikte başa çıkmanın özel biçimlerine de kaynaklık etmektedir. Kader inancı sabır, Allah'ın takdirine rıza ve teslimiyetle birlikte "her şeyde bir hayır vardır, Mevla görelim neyler neylerse güzel eyler" gibi kabullenmeyi destekleyen ifadelerle olumlu dinî başa çıkmanın bir enstrümanı olabilir. Dindarlığın telafi fonksiyonunu ortaya çıkaran kader inancı özellikle başa çıkılması güç yaşam krizlerinde rahatlatıcı ve yatıştırıcıdır. Kabullenme gerektiren kayıp gibi durumlarda din, kader inancının yardımıyla olayların nedenselliği üzerinde yoğunlaşmaktan alıkoymak suretiyle anlamlandırma sürecine yardım eder. Kader olgusu olumsuz dinî başa çıkmanın da bir enstrümanı olabilir. Bireyin "Allah'ım ne günahım vardı da bu derdi bana verdin? Kaderimi neden kötü yazdın?” gibi kadere isyanı çağrıştıran sözleri, negatif duyguların yoğunlaşmasına yol açabilir. Kaderi gündeme getirerek ve cezalandırıcı Tanrı algısını merkeze alarak yaşananları anlamlandırmaya çalışmak, bireyin karamsarlığa düşüp umudunu yitirmesine sebep olabilir ve başa çıkma sürecini etkisizleştirebilir. ${ }^{65}$

Pargament ve arkadaşları üç farklı olumlu dinî başa çıkma biçimi olduğunu tespit etmişlerdir. Bunlar işbirlikçi (collobarative), erteleyici (deferring) ve kişisel yönelimli (selfdirecting) dinî başa çıkma yöntemleridir. Kişisel yönelimli dinî başa çıkmada birey kendi Tanrı vergisi kaynaklarına dayanarak kendisini yönlendirmekte, sorumlulukla karşılaş̧ı̆̆ında aktif problem çözme durumunu almaktadır. ${ }^{66}$ Ertelemeci dinî başa çıkma tarzını seçen birey ise çözümün Tanrı'nın aktif çabaları sayesinde ortaya çıkmasını beklemektedir. ${ }^{67}$ Işsirlikçi yönelimde sorumluluk Tanrı

62 Kenneth I. Pargament vd., "Religion and the Problem Solving, Process: Three Styles of Coping", Journal for the Scientific Study of Religion 27/1 (1988), 90.

63 Halil Ekşi, Başaçıkma, Dinî Başaçıkma ve Ruh Sağlı̆̆ Arasındaki İliş̧i Üzerine Bir Araştırma (Bursa: Uludağ Üniversitesi, Sosyal Bilimler Enstitüsü, Doktora Tezi, 2001), 23.

64 Lazarus - Folkman, Stress, Appraisal and Coping, 150-151; Jeffrey P Bjorck - Lawrence H. Cohen, "Coping With Threats, Losses and Challenges", Journal of Social and Clinical Psychology 12/1(1993), 58, 68.

65 Yapıcı, "Kovid-19 Küresel Salgınına Dinî ve Din Dışı Yüklemeler, Tanrı'nın Gazabı mı? İnsanın Suçu mu?”, 126; İbrahim Coşkun, "Engellilik-Kader İlişkisi ve Genom Projesi İle Bu İlişkinin Geleceğine Dair Tartışmaların Değerlendirilmesi “, I. Uluslararası Engellilikve Din Sempozyumu (İstanbul: Yeditepe Ofset Yayıncılık, 2016), 76; Doğan, Sabır Psikolojisi, 162.

${ }_{66}$ Pargament vd., "Religion and the Problem Solving, Process: Three Styles of Coping", 91.

67 Kenneth Pargament, “Acı ve Tatlı: Dindarlı̆̆ın Bedelleri ve Faydaları Üzerine Bir Değerlendirme”, çev. Ali Ulvi Mehmedoğlu, Çukurova Üniversitesi İlahiyat Fakültesi Dergisi 5/1 (Ocak-Haziran 2005), 286; Kenneth I. Pargament vd., "Patterns of Positive and Negative Religious Coping with Major Life Stressors", Journal for the Scientific Study of Religion 37/4 (1998), 712. 
ile birey tarafından paylaşılmaktadır. Her iki katılımcı birlikte problem çözmeye çalışan, sürece aktif katkıda bulunan ortaklar olarak düşünülmektedir. ${ }^{68}$

İslam dinine mensup ve dinî başa çıkma yöntemlerini kullanan bireylerin kader inancına sahip olduğunu varsayarsak bu bireylerin kader algılarına Cebrî, Mu'tezilî, Eş'arî ve Mâtürîdî yaklaşımların etki edeceği düşünülebilir. Cebrî kader algısına sahip olan bireyin ertelemeci dinî başa çıkmayı; Mu'tezilî kader algısına sahip olanın kişisel yönelimli dinî başa çıkmayı; Eş'arî kader algısına sahip olanın ertelemeci ve işbirlikçi dinî başa çıkmayı, Mâtürîlî kader algısına sahip olanın ise kişisel yönelimli, ertelemeci ve işbirlikçi dinî başa çımmayı tercih edebileceği söylenebilir. ${ }^{69}$ Kişisel yönelimli dinî başa çıkma biçiminde Allah'ın insanlara özgürlük verdiği inanciyla hareket edilmektedir. Kader algısıla uyumlu olarak birey bütün sorumluluğu kendi üzerine alarak aktif bir başa çıkma yöntemi kullanabilir. Ertelemeci dinî başa çıkmada tamamen Allah'a havale edip pasif bir tutumu tercih etmek vardır. Bu yaklaşım insanın kaderi üzerinde etkisinin olmadığı anlayışından besleniyor olabilir. Ancak yapılacak hiçbir şey kalmadığında genellikle aktif dinî başa çıkma yöntemini tercih edenler tarafından da ertelemeci yaklaşım kullanılabilir. Cebrî kader algısı fatalizme benzer görülse de başa çıkma sürecinde "Allah'a yönelme, olacakları Allah'ın iradesine bırakma, Allah'ın kendisine her şeyin en iyisini vereceğine inanma gibi" pozitif düşünceler yer aldığından kısmen olumlu dinî başa çıkmanın pozitif etkilerini ortaya çıkarabilir. Ancak bu tarz başa çıkma pasif kalmayı içerdiğinden problem çözücü etkili bir başa çıkma sağlamayabilir. İşbirlikçi dinî başa çıkmayı tercih edenler ise dua, tevekkül, şükür, sabır gibi dinî başa çıkma araçları ile Allah'ın yardımını yanlarında hissedebilirler. Diğer taraftan kendi kaderlerinde söz sahibi olduklarını düşünerek bizzat sorumluluk almak suretiyle problem çözücü, etkili bir başa çıkma yöntemi kullanmış olabilirler.

Kader olgusunun dinî başa çıkma ile üç boyutlu ilişkisinden söz edilmektedir. Birinci boyut, kader inancının başa çıkma sürecinin "bir parçası" olmasıdır. Travmatik yaşantılar, kayıplar, başarısızlıklar gibi istenmeyen ve başa çımayı zorunlu hale getiren yaşantılarda din, başa çıkmanın en başat aracı olabilir. Kabullenme gerektiren bu gibi durumlarda kader inancı, teselli ve yatıştırma etkisiyle sürecin sabredilebilir olduğu düşüncesini kazandırarak duygu odaklı bir başa çıkmanın parçası olabilir. İkinci boyut kader inancının başa çıkmaya "yardımcı" olmasıdır. Kader inancı, yaşananları anlamlandırma noktasında başa çıkmaya yardımcı olabilir. Olayların Tanrı'nın irade ve kudretine bağlanması, yaşananların tesadüf olmayıp ilâhî bir planın parçası olduğu düşüncesi gibi kader eksenli yüklemeler, dindarlığın telafi fonksiyonunu aktifleștirebilir. Üçüncü boyut kader inancının başa çıkma sürecinin “doğal bir ürünü” olmasıdır. Kader eksenli açılamalara daha fazla ihtiyaç duyulan travmatik yaşantılar, hayatın zorlukları gibi durumlar bireylerin dinden destek aldıkları, dinî pratik ve uygulamalara yöneldikleri, dinî tecrübelere açık oldukları ve dinî gelişim yolunda ivme kazandıkları özel zamanlardır. Bu tür yaşam tecrübeleri bir yandan bireylerin kader algılarını biçimlendirirken diğer yandan dinî inançlarını ve buna bağlı

68 Pargament vd., "Religion and the Problem Solving, Process: Three Styles of Coping”, 91-92.

69 Gürses, "Yükleme Teorisi ve Din İlişkisi Üzerine Bir Değerlendirme”, 374; Coşkun, "Engellilik-Kader İlişkisi ve Genom Projesi İle Bu İlişkinin Geleceğine Dair Tartışmaların Değerlendirilmesi “, 76. 
olarak kadere olan inançlarını güçlendirebilir. Böylece kader inancı dinî başa çıkmanın bir ürünü olabilir..$^{70}$

\section{Yöntem}

\subsection{Araștırma Modeli}

Araştırmanın yöntemi nitel araştırma yaklaşımına dayalı olgu bilim araştırma deseni olarak belirlenmiştir. Olgu bilim (phenomelogy) çalışmaları farkında olunan ancak derinlemesine ve ayrıntılı bir anlayışa sahip olunmayan olgulara odaklanmaktadır. Bu tür araştırmalarda veri kaynakları araştırmanın odaklandığı olguyu yaşayan ve bu olguyu dışa vurabilecek bireyler ya da gruplardır. ${ }^{71}$ Araştırmada bireylerin kader algılarını ortaya çıkarmak için derinlemesine analiz yapmaya imkan veren metafor analizi yöntemi kullanılmıştır. Metafor analizi, bireylerin her hangi bir konuya ilişkin algılarını belirlemek amacıyla sosyal bilimlerde son yıllarda sıklıkla kullanılan bir yöntemdir.

Metaforla ilgili literatürde "geleneksel metafor kuramı" ve "kavramsal metafor kuramı" olmak üzere iki kuramdan söz edilmektedir. Geleneksel kuram metaforu sözcüklere dayalı mecazî anlatım, retorik ve belagat, bir söz sanatı olarak görürken kavramsal metafor kuramı bilişsel boyuta dikkat çekmektedir. Kavramsal metafor, düşünce ile ilgili bir mesele olup dil kullanımının ötesindedir. Ayrıca o, retorik bir araç olmayıp dünyayı algılama ve anlamlandırmaya yarayan bilişsel bir süreçtir. Bu mekanizmanın temel işlevlerinden biri soyut kavram alanını, somut kavram alanıyla ifade ederek anlaşılır kılmaktır. Bireyler, metafor kullanarak bildikleri bir durum ya da kavramı daha iyi bildikleri bir durum ya da nesneyi kullanarak daha iyi tanımlama yoluna giderler. Böylece tanımlamaya çalıştıkları durum ya da kavrama ilişkin olarak zihinlerindeki temel kodlamaya yönelik ipuçları verirler. ${ }^{72}$ Dolayısıyla metaforlar bireylerin kavramlarla ilgili algısını ortaya çıkarmak için kullanılabilecek en etkili bilişsel yapılardır. Metafor üretmek, bir kavramı başka bir kavramla tanımlamaya çalışmaktan farklı bir ilişkilendirmedir. Bireyin metafor üretilen kavramla ilgili bilinçaltındaki izleri, bilişsel sistemindeki bilgi birikimi, yaşamsal tecrübeleri oluşturduğu metafora yansımaktadır. ${ }^{73}$ Kader kavramı hem soyut hem de karmaşık bir olgunun sembolik karşılı̆̆ıdır ve açıklanması zordur. Bu nedenle metafor analizi yönteminin bu araştırmanın amacına daha uygun olduğu düşünülmüştür.

70 Mebrure Doğan, Acıdan Erdeme Yolculuk - Travma Sonrası Gelişim Psikolojisi ve Din (İstanbul: Çamlıca Yayınları, 2020), 228; Kartopu, "Psikolojik Açıdan Kadere İman Nedir Ne Değildir?”, Kader Nedir? Ne Değildir?, ed. Adnan Demircan (Ankara: Fecr Yayınları, 2019), 19-21; Kenneth I. Pargament, "Tanrım Bana Yardım Et: Din Psikolojisi Açısından Başa Çıkmanın Teorik Çatısına Doğru”, çev. Ahmet Albayrak, Tabula-Rasa Felsefe-Teoloji 9 (2003), 216-222; Hayati Hökelekli, Din Psikolojisi (Ankara: TDV Yayınları, 1998), 91.

71 Şener Büyüköztürk vd., Bilimsel Araştırma Yöntemleri (Ankara: Pegem Yayınları, 2014), 20.

72 Özlem Karaırmak - Berna Güloğlu, "Metafor: Danışan ve Psikolojik Danışman Arasındaki Köprü”, Türk Psikolojik Danışma ve Rehberlik Dergisi 4/37 (2012), 123-124; Ahmet Naim Çiçekler - Timur Aydın, "Kavramsal Metafor Kuramı ve Belagat: Karşılaştırmalı bir İnceleme”, RumeliDE Dil ve Edebiyat Araştırmaları Dergisi 16 (2019), 6-23; Mehmet Nuri Gömleksiz vd., "Sosyal Bilgiler Öğretmen Adaylarının Bir Değer Olarak Demokrasi Kavramına İlişkin Metaforik Algıları”, Değerler Eğitimi Dergisi 10/24 (2012), 82; Durmuş Ümmet, “Üniversite Mezunu Evli Bireylerin Evlilik Algıları Üzerine Metaforik Bir İnceleme”, Kalem Eğitim ve İnsan Bilimleri Dergisi 7/1 (2017), 212.

73 Levent Eraslan, “Sosyolojik Metaforlar”, Akademik Bakış Dergisi 27 (2011), 1; Aysun Güneş - Mehmet Fırat, “Açık ve uzaktan öğrenmede metafor analizi araştırmaları”, Açıöğretim Uygulamaları ve Araştırmaları Dergisi 2/3 (2016), 124. 


\section{2. Çalışma Grubu}

Metafor çalışmaları, düşünceyi ifade etme becerisiyle ilişkili olduğundan araştırmada örneklem grubu olarak üniversite öğrencileri seçilmiştir. Gereken etik kurul izni Afyon Kocatepe Üniversitesi'nden alındıktan sonra araştırma internet üzerinden yürütülmüş, araştırmaya farklı üniversitelerin lisans bölümlerinden 211 üniversite öğrencisi katılmıştır. Yapılan incelemede metafor çalışmasına uygun olmayan veriler analizden çıkarılmış ve 163 veri seti ile çalışmaya devam edilmiştir.

\subsection{Veri Toplama Arac1}

Araştırma için hazırlanan formda öncelikle katılımcı öğrencilerin demografik özelliklerini belirlemek için sorular sorulmuştur. Ardından kaderle ilgili metafor oluşturabilmeleri için metaforun ve öğelerinin ne olduğu hakkında kısa bir bilgi verilmiş ve forma örnek bir metafor cümlesi eklenmiştir. Katılımcılardan “Kader,... gibidir. Çünkü...” cümlesini tamamlamaları ve ilave olarak kader denince akıllarına gelen beş kavram ya da kelimeyi sıralamaları istenmiştir. Bu kavramlar, metaforların açıklamaları yeterince açık olmadığında öğrencilerin kader algılarını daha da netleștirebilmek amacıyla analizde kullanılmıştır.

\subsection{Verilerin Analizi}

Araştırmada öncelikle veriler bilgisayar ortamında düzenlenmiş, metafor belirtilmemiş, belirtilmiş olsa bile açıklama kısmı doldurulmamış, yeterince anlaşılır olmayan formlar analiz dışında bırakılmıştır. Veriler sıraya konulduktan sonra her bir veri setine numara verilmiş, uygun olduğu düşünülen metaforlar alfabetik sıraya göre dizilmiş, frekans ve yüzdelikleri ile birlikte tablo haline getirilmiştir. Daha sonra metaforlarda kadere yüklenen anlamlara göre aynı temayı içeren gruplar oluşturulmuş, gruplamada metafordan ziyade onu açıklayan "çünkü..." kısmı esas alınmıştır. Kategoriler ve altında toplanan temalardaki metaforlar ilişkisel açıdan yeniden gözden geçirilmiş ve sonrasında geçerlilik ve güvenirliğin sağlanması için çalışma iki uzman tarafından incelenmiştir. Oluşturulan kavramsal kategorilerin doğru isimlendirilmesi konusunda uzmanların da görüşleri alındıktan sonra gereken düzenlemeler yapılmış ve çalışmaya son hali verilmiştir.

\section{Bulgular}

Tablo.1 Örneklemin Demografik Özellikleri

\begin{tabular}{|l|l|l|}
\hline Cinsiyet & N & \% \\
\hline Kadın & 119 & 73 \\
\hline Erkek & 44 & 27 \\
\hline Bölüm & N & \% \\
\hline Fen Bilimleri & 17 & 10,43 \\
\hline Sosyal Bilimler & 94 & 57,28 \\
\hline Sağllk Bilimleri & 51 & 31,28 \\
\hline Öznel Dindarlık Algis1 & $\mathbf{N}$ & $\%$ \\
\hline Herhangi bir dine inanmiyorum & 4 & 2,4 \\
\hline Düşük (1,2,3) & 19 & 11,6 \\
\hline Orta $(4,5,6)$ & 76 & 46,6 \\
\hline İyi $(7,8)$ & 49 & 30 \\
\hline Çok İyi $(9,10)$ & 15 & 9,2 \\
\hline Toplam & 163 & 100,0 \\
\hline
\end{tabular}


Araştırmanın yürütüldüğü örneklem grubunun yaşları 17 ile 45 arasında değişmekte olup yaş ortalamaları 21.5'tir. Tablo 1'de görüldüğü gibi örneklemin \%73'ünü kadın, \%27'sini erkek katılımclar oluşturmaktadır. Araştırmaya hemen her fakülteden öğrenci katılmış, çeşitlilik fazla olduğundan öğrenim görülen lisans programları Fen Bilimleri (\%10,43), Sosyal Bilimler $(\% 57,28)$, Sağlık Bilimleri $(\% 31,28)$ olmak üzere sınıflandırılmıştır. Ayrıca öğrencilerden kendi dindarlıklarını 10 üzerinden değerlendirmeleri istenmiş, katılımcıların \%2,4’ü herhangi bir dine inanmadığını belirtmiştir. Veriler düşük, orta, iyi ve çok iyi olmak üzere sınıflandırılmış, katılımcıların \%11,6'sının öznel dindarlık algılarının düşük, \%46,6'sının orta, \%30'unun iyi ve $\% 9,2$ 'sinin çok iyi düzeyde olduğu görülmüştür.

Tablo 2. “Kader” Kavramına İlişkin Oluşturulan Metaforlar

\begin{tabular}{|c|c|c|c|c|c|}
\hline Metafor Adı & $\mathrm{f}$ & Metafor Adı & $\mathrm{f}$ & Metafor Adı & $f$ \\
\hline 1. Yol & 18 & 37. Değişmez kanun & 1 & 73. Kum saati & 1 \\
\hline 2. Çark & 5 & 38. Deniz & 1 & $\begin{array}{l}\text { 74. Küçük bir çocuğa } \\
\text { verilen şeker }\end{array}$ & 1 \\
\hline 3. Kitap & 5 & 39.Dipsiz bir kuyu & 1 & 75. Lamba & 1 \\
\hline 4. Harita & 4 & 40. Direksiyon & 1 & 76. Matematikteki x & 1 \\
\hline 5. Kalem & 4 & 41. Düzey & 1 & 77. Meyve ağacı & 1 \\
\hline 6. Senaryo & 4 & 42. Ferman & 1 & 78. Mucize & 1 \\
\hline 7. Yol Ayrımı & 4 & 43. Film & 1 & 79. Müteşabih ayet & 1 \\
\hline 8. Çizgi & 3 & 44. Freni tutmayan araba & 1 & 80. Navigasyon & 1 \\
\hline 9. Gemi & 3 & 45. Geçmişim & 1 & 81. Nehir & 1 \\
\hline 10. Labirent & 3 & 46. Gelecek & 1 & 82. Otobüs şoförü & 1 \\
\hline 11. Saat & 3 & 47. Gökyüzü & 1 & 83. Para & 1 \\
\hline 12. Sığınak & 3 & 48. Göz & 1 & 84. Piyango & 1 \\
\hline 13. Akarsu & 2 & 49. Günah keçisi & 1 & 85. Roman & 1 \\
\hline 14.Hamur & 2 & 50. Güneş & 1 & 86. Rüzgar & 1 \\
\hline 15. Hapishane & 2 & 51. Günlük & 1 & 87. Rüzgara karş1 uçmak & 1 \\
\hline 16. Liman & 2 & 52. Hava & 1 & 88. Saksıdaki çiçek & 1 \\
\hline 17. Pusula & 2 & 53. Hayallerim & 1 & 89. Sinırları belirleyen tel & 1 \\
\hline 18. Su & 2 & 54. Hayat & 1 & 90. Siyasiler & 1 \\
\hline 19. Zaman & 2 & 55. Hayatın odağı & 1 & 91. Sürpriz kutu & 1 \\
\hline 20. Ağaçta yaprak & 1 & 56. Hediye paketi & 1 & 92. Sürpriz yumurta & 1 \\
\hline 21. Akan derede yüzmek & 1 & 57. Hikaye & 1 & 93. Süpürge & 1 \\
\hline 22. Alınyazısı & 1 & 58. İki seçenek & 1 & 94. Şans & 1 \\
\hline 23. Alışveriş merkezi & 1 & 59. İnsanın gölgesi & 1 & 95. Tasma & 1 \\
\hline 24. Anne & 1 & 60. İnteraktif kitap & 1 & 96. Terazi & 1 \\
\hline 25. Anne-baba & 1 & $\begin{array}{l}\text { 61. İp cambazının ipin } \\
\text { üzerinde yürümesi }\end{array}$ & 1 & 97. Tespih & 1 \\
\hline 26. Araba kullanmak & 1 & 62. İradenin üstünde bir güç & 1 & 98. Tiyatro & 1 \\
\hline 27. Asansör & 1 & 63. İsteğe bağl1 yazı & 1 & 99. Tohum & 1 \\
\hline 28. Ayna & 1 & 64. Kapalı kutu & 1 & 100. Tükenmez kalem & 1 \\
\hline 29. Baba-evlat ilişkisi & 1 & 65. Kapitalizm & 1 & $\begin{array}{l}\text { 101. Tünelin sonundaki } \\
\text { 1ş1k }\end{array}$ & 1 \\
\hline 30. Balık için su & 1 & $\begin{array}{l}\text { 66. Kaptanın dümende } \\
\text { olduğu dalgalı deniz }\end{array}$ & 1 & $\begin{array}{l}\text { 102. Üniversite tercih } \\
\text { sonuçları }\end{array}$ & 1 \\
\hline $\begin{array}{l}\text { 31. Belirlenmiş rotada } \\
\text { kaybedilmiş adres }\end{array}$ & 1 & 67. Kaya & 1 & 103.Yaydan çıkmış ok & 1 \\
\hline
\end{tabular}




\begin{tabular}{|l|l|l|l|l|l|}
\hline 32. Belirsizlik & 1 & 68. Kısmet & 1 & 104. Yürümek & 1 \\
\hline $\begin{array}{l}\text { 33. Beyaz kağıda sütle yazılmış } \\
\text { yazı }\end{array}$ & 1 & 69. Kıyafet & 1 & 105. Zaman Makinası & 1 \\
\hline 34. Bisiklet sürmek & 1 & 70. Kontrol edilemeyen kuş & 1 & 106. Zorunluluk & 1 \\
\hline 35. Çok bilinmeyenli denklem & 1 & 71. Kontrolsüz bir hortum & 1 & & \\
\hline 36. Çoktan seçmeli sınav & 1 & 72. Koruyucu melek & 1 & & \\
\hline
\end{tabular}

Tablo 2 incelendiğinde araştırmada "kader" kavramına ilişkin 106 metafor üretildiği görülmektedir. Üniversite öğrencilerinin ilk on sırada en fazla belirttikleri metaforlar; "yol, kitap, çark, senaryo, kalem, harita, yol ayrımı, sığınak, çizgi, gemi” metaforlarıdır. Diğer dokuz metaforun üç ile iki arasında tekrar edilme sıklı̆̆ olup 87 metaforun bir kez tekrarlandığı görülmektedir.

Araştırmada katılımcılardan kader denildiğinde akıllarına gelen kelime ve kavramları yazmaları istenmiştir. Katılımcılar en fazla "Allah (35), İman-inanç (28), Takdir/ Mukadderat (19), Din (8), Teslimiyet/Tevekkül (16), Kaza (15)" gibi inançla ilişkili kelimeleri tercih etmişlerdir. Bununla birlikte "Yol (34) ve Hayat/Yaşam (48)" kavramları en sık tekrarlanan kelimelerdendir ki bu, kaderin aynı zamanda yaşamsal bir olgu olarak algılandığını göstermektedir. Diğer taraftan bazı katılımcılar kader kelimesinin yerine sıklıkla kullanılan "Alın Yazısı (31), Yazg1 (18), Kısmet/Nasip (30), Şans/Baht (13)" gibi kelimeleri yazmışlardır. Kaderi zamanla ilişkilendiren katılımcılar “Zaman (11), Gelecek (15), Geçmiş (5)” kelimelerini tercih etmiş, "Seçim-seçenek (19), Tercih (17), İrade (19), Özgürlük (3)" gibi kavramları seçenler ise insanın kaderinde söz sahibi olmasına verdikleri öneme işaret etmişlerdir. Bu sonuçlar katılımcıların oluşturdukları metaforlarla şekillenen kategoriler ve temalarla örtüşmektedir.

\section{Tablo 3. Kategoriler ve Alt Temalar}

\begin{tabular}{|c|c|c|c|}
\hline \multicolumn{2}{|c|}{ Kategori 1: Nitelik Bağlamında Kader } & \multirow{2}{*}{$\begin{array}{c}\text { Metafor } \\
\text { Say1s1 }\end{array}$} & \multirow{2}{*}{$\begin{array}{c}\% \\
25,7\end{array}$} \\
\hline \multirow{5}{*}{ 胥 } & 1. Değişmeyen/Belirlenmiş Olgu Olarak Kader & & \\
\hline & 2. Yönlendirilebilen/Tercih Edilebilen Olgu Olarak Kader & 52 & 31,9 \\
\hline & 3. Bilinmeyen/Kontrol edilemeyen Olgu Olarak Kader & 32 & 19,6 \\
\hline & 4. Hem Belirlenmiş Hem de Yönlendirilebilen Olgu Olarak Kader & 24 & 14,7 \\
\hline & 5. Savunma Mekanizması Olarak Kader & 8 & 4,9 \\
\hline \multicolumn{4}{|c|}{ Kategori 2: İnanç-Özgürlük Bağlamında Kader } \\
\hline \multirow{6}{*}{$\frac{\text { శี }}{\text { בี้ }}$} & 1. Fatalist Eğilimli Kader Olgusu & 44 & 27 \\
\hline & 2. Salt İnanç Temelli Kader Olgusu & 13 & 8 \\
\hline & 3. İnanç Temelli İradeci Kader Olgusu & 33 & 20 \\
\hline & 4. İnanç Temelli Cebrî Kader Olgusu & 19 & 11,6 \\
\hline & 5. İnanç Temelli Olmayan İradeci Kader Olgusu & 36 & 22 \\
\hline & 6. Kader Karşıtllı̆̆ & 7 & 4,3 \\
\hline
\end{tabular}

Tablo 3’te görüldüğü gibi katılımcıların kader ile ilgili ürettikleri metaforlarla ilgili öncelikle alt temalar oluşturulmuş, buna uygun olarak üst kategoriler oluşturulmuştur. Metaforlar temalara ayrıştırılırken açıklamalar dikkate alındığından farklı katılımcıların ürettikleri metaforlar aynı olsa bile yükledikleri anlam farklı olduğunda farklı temalar altında yer almıştır. 


\subsection{Nitelik Bağlamında Kader}

\section{Tablo 4. Değişmeyen/Belirlenmiş Olgu Olarak Kader Teması ${ }^{*}$}

\begin{tabular}{|c|c|c|}
\hline & Nitelik Bağlamında Kader & Metaforlar \\
\hline & & $\begin{array}{l}\text { Harita (2), Ferman, Güç, Alınyazısı, Kaya, Gölge, Saat (2), Yol (3), } \\
\text { Gemi, Kalem, Pusula, Ağaçtaki yaprak, Zorunluluk, Su, Nehir, } \\
\text { Gökyüzü, Labirent (2), Geçmişim, Anne, Kitap (2), Hikâye, Film, } \\
\text { Hayatın odağı, Çizgi, Göz, Asansör, Mahkum, Plan, Tükenmez kalem, } \\
\text { Kanun, Çizgi, Senaryo, Anne-baba, Zaman, Yaydan çıkmış ok. }\end{array}$ \\
\hline & \multicolumn{2}{|c|}{$\begin{array}{l}\text { “Kader ferman gibidir. Çünkü kader senin hakkında yazılmış geleceğine şekil veren değişmeyen bir } \\
\text { fermandır.” (K, 22, AKÜ İslami İlimler F., 9) } \\
\text { "Kader geçmişim gibidir. Çünkü geçmişimi değiştiremem ama bu geleceğimin kötü olacağı anlamına } \\
\text { gelmez." (E, 18, Bilkent Üniversitesi, Makine Mühendisliği, 3) } \\
\text { "Kader uzun ve çetrefilli bir yol gibidir. Çünkü ilerleyerek yeni ve farklı şeylerle karşılaşırız. Kader } \\
\text { olanlara boyun eğmemizi emreden bir olgu, İlahi olarak belirlenmiş gelecektir.” (K, 21, AYBÜ, Sosyal } \\
\text { Hizmet, 5) } \\
\text { "Kader insanın hayatında keskin bir çizgi gibidir. Çünkü önceden planlanmış bir yazıyı yaşarız." (K, } \\
\text { 20, AYBÜ, Din ve Konuşma Terapisi, 6) } \\
\text { "Kader plan gibidir. Çünkü daha önceden yazılmıştır.” (K, 19, Adnan Menderes Ü., Psikoloji, 6) }\end{array}$} \\
\hline
\end{tabular}

Tablo 4'te bazı katılımcıların kader algılarında kaderin önceden belirlenmişliği ve değiştirilemez oluşu ile ilgili düşüncenin merkezi yer tuttuğu görülmektedir. Veriler incelendiğinde bu metaforların aynı zamanda fatalistik eğilime ve cebrî kader algısına işaret ettiği göze çarpmaktadır. Buna göre bu bireylerin kader algılarının kendilerini hayat problemleri karşısında çözümleyici bir davranışa değil, pasif kalmaya iteceği söylenebilir. ${ }^{74}$ Araştırmanın bulgularına göre de katılımcların \%25,7'si kaderi değişmeyen/belirlenmiş bir olgu olarak değerlendirmişlerdir. Yapılan bir araştırmada katılımcıların \%63’ünün kaderin değişmeyeceğine inandıkları belirlenmiştir. ${ }^{75}$ Sakarya'da yapılan bir araştırmada ise katılımcıların \%26,6'sı insanın kendi kaderini değiştiremeyeceği, \%71,4’ü ise insanın kaderinin doğduğunda belirlendiği düşüncesine sahip bulunmuştur. ${ }^{76}$

Metaforların açılama örneklerinde parantez içinde verilen bilgilerin sıralaması: (Cinsiyet, yaş, öğrenim görülen üniversite/fakülte/bölüm ve öznel dindarlık algısı) şeklindedir.

74 Kaya - Bozkur, "Kadercilik Eğilimi İle Özyeterlik İnancı ve Savunma Mekanizmaları Arasındaki İlişkinin İncelenmesi", 126.

75 Elif Batman, Yaşamın Zorluklarıyla Başa Çıkmada Kader İnancının Rolü (Adana: Çukurova Üniversitesi Sosyal Bilimler Enstitüsü, Yüksek Lisans Tezi, 2008), 43.

76 Mücahit Şentürk, Sakarya Halkının Kader Anlayışı (Sakarya: Sakarya Üniversitesi, Sosyal Bilimler Enstitüsü, Yüksek Lisans Tezi, 2013), 59, 63. 


\section{Tablo 5. Yönlendirilebilen/Tercih Edilebilen Olgu Olarak Kader Teması}

\begin{tabular}{|c|c|c|}
\hline & Nitelik Bağlamında Kade & Metaforlar \\
\hline & $\begin{array}{l}\text { Yönlendirilebilen/Tercih } \\
\text { Edilebilen Olgu Olarak } \\
\text { Kader }\end{array}$ & $\begin{array}{l}\text { Araba kullanmak, Su, Hamur (2), Saksıdaki Çiçek, Bisiklet sürmek, } \\
\text { Kalem (3), Roman, Yol (11), Navigasyon, Zaman makinası, Hayat, Kum } \\
\text { saati, Tohum, Direksiyon, Akarsu (2), Baba-evlat ilişkisi, İp cambazının } \\
\text { ipin üzerinde yürümesi, Pusula, Saat, Meyve ağacı, Yürümek, Ayna, } \\
\text { Çoktan seçmeli sınav, Rüzgara karşı uçmak, Çizgi, Balık için su, Çok } \\
\text { bilinmeyenli denklem, Çarkıfelek(2), Üniversite tercih sonuçları, İki } \\
\text { seçenek, Yol ayrımı, Alışveriş merkezi, Kıyafet, İnteraktif kitap, Harita, } \\
\text { Hayallerim, Senaryo. }\end{array}$ \\
\hline 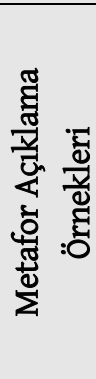 & \multicolumn{2}{|c|}{$\begin{array}{l}\text { "Kader kalem gibidir. Çünkü insan tıpkı kalemle istediğini yazabildiği gibi kendi kaderini yazar.” (K, } \\
\text { 22, Osmangazi Ü. İlahiyat F., 8) } \\
\text { "Kader yol gibidir. Çünkü bir yere ulaşmak için pek çok yol vardır fakat bu yollardan birini seçmek } \\
\text { bize bırakıllmıştı." (K, 21, Uludağ Ü. Endüstri Mühendisliği, 6) } \\
\text { "Kader, direksiyon gibidir. Çünkü sen nereye yönlendirirsen oraya döner.” (K, 19, Muğla Sıtkı Koçman } \\
\text { Ü., Bilişim Sistemleri Mühendisliği, 6). } \\
\text { "Kader akarsu, biz ise elinde kürek olan bir insan gibiyiz. Çünkü küreğimizle suyun nereye doğru } \\
\text { akacağını belirleyebiliriz." (E, 18, AKÜ, Psikoloji, 8) } \\
\text { "Kader yol ayrımları gibidir. Çünkü bize seçenekler sunar.” (K, 18, AYBÜ, Hukuk F., 4) }\end{array}$} \\
\hline
\end{tabular}

Tablo 5’te görüldüğü üzere katılımcıların bir kısmı nitelik olarak kaderin birey tarafından yönlendirilebilir olduğuna ve bireye tercih hakkının verildiğine işaret eden metaforlar kurmuşlardır. Katılımcılar "araba kullanmak, bisiklet sürmek, direksiyon, akarsu, su, hamur" gibi metaforlarla kaderin yönlendirilebileceğini; "çoktan seçmeli sınav, üniversite tercih sonuçları, iki seçenek, yol ayrımı" gibi metaforlarla çeşitli seçenekler arasında tercih hakkının olduğunu belirtmek istemişlerdir. Konuyla ilgili olarak Düzgün de "Eğer kendisi için her şey belirlenmiş olsaydı, insanın yaşamında 'keşke'lere de yer olmazdı. Keşke şu şekilde değil de bu şekilde davransaydım diyen bir insan, aslında bütün süreci kendisinin kontrol ettiğini itiraf etmektedir." demektedir. ${ }^{77}$ Hayatlarında söz sahibi olduklarına ve problemlerine çözüm bulmada kendi çabalarının değerli olduğuna inandıkları için bu bireylerin kader algılarının, kendilerini hayat karşısında aktif bir tutum sergilemeye götüreceği söylenebilir.

\section{Tablo 6. Bilinmeyen/Kontrol Edilemeyen Olgu Olarak Kader Teması}

\begin{tabular}{|c|c|c|}
\hline & Nitelik Bağlamında Kader & Metaforlar \\
\hline 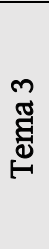 & $\begin{array}{l}\text { Bilinmeyen/Kontrol } \\
\text { Edilemeyen Olgu } \\
\text { Olarak Kader }\end{array}$ & $\begin{array}{l}\text { Sürpriz yumurta, Yol (3), Kapalı kutu, Beyaz kağıda sütle yazılmış yazı, } \\
\text { Müteşâbih âyetler, Rüzgar, Gemi (2), Matematikteki x, Para, Deniz, } \\
\text { Koruyucu Melek, Tünelin sonundaki 1şı, Şans, Sürpriz kutu, Akan derede } \\
\text { yüzmek, Dipsiz bir kuyu, Hediye paketi, Gelecek Mucize, Hava, Çark (2), } \\
\text { Tasma, Piyango, Kontrol edilemeyen kuş, Kısmet, Kontrolsüz hortum, } \\
\text { Zaman (2), Güneş. }\end{array}$ \\
\hline
\end{tabular}

77 Şaban Ali Düzgün, “Kader'i Farklı Kategoriler İçinde Okumanın İmkanı”, Kelam Araştırmaları Dergisi 11/2 (2013), 6. 


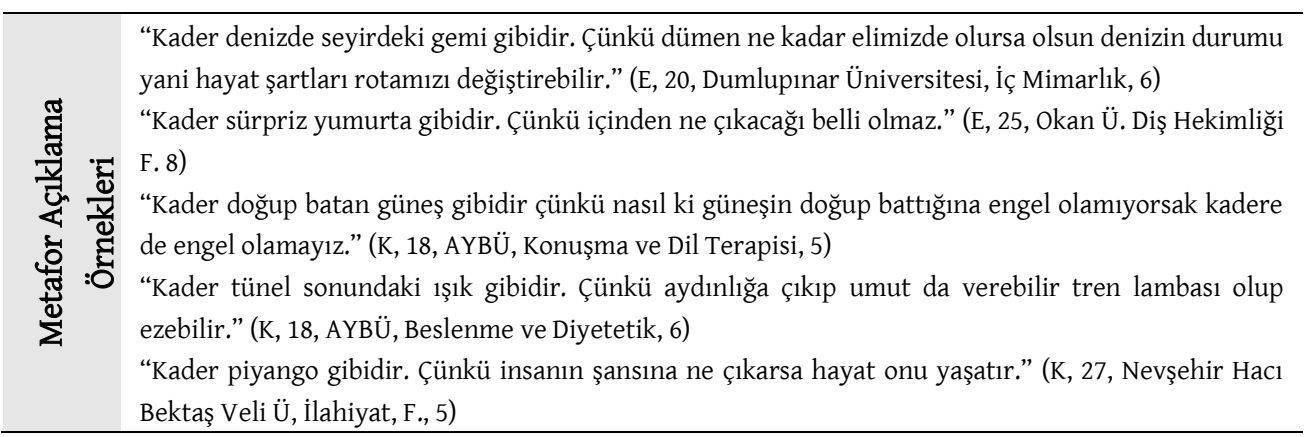

Tablo 6'da niteliksel olarak kaderin bilinmeyen, belirsiz ve kontrol edilemeyen özelliklere sahip olduğunu düşünen katılımcıların oluşturdukları metaforlar bulunmaktadır. Katılımcıların oluşturdukları "sürpriz yumurta, kapalı kutu, Matematikteki x, şans" gibi metaforlar kaderin belirsiz olduğunu; "mucize, çark, piyango, kontrol edilemeyen kuş, kontrolsüz hortum" gibi metaforlar kontrol edilemeyen bir olgu olduğunu anlatmaktadır. Hayattaki belirsizlikler bireyde kaygıya neden olabileceği gibi birey her şart ve durumda yaşananları kontrol etme ihtiyacı duymaktadır. ${ }^{78}$ İnsanın ne ile karşılaşacağının bilinemeyeceği ve olayların kontrol edilemeyeceği düşüncesi ile şekillenen bir dünya varsayımı, bireyde güvensizlik hissi oluşturmaktadır. ${ }^{79}$ Dolayısıyla bu metaforları üreten bireylerin problemler karşısında yapılacak bir şey olmadığı düşüncesine kapılarak pasif bir tutumu benimsemeleri ihtimal dâhilindedir. Ancak her ne olursa olsun yaşananların ilâhî kontrol altında olduğuna inanç, kontrol bireyin kendisinde olmasa bile güvensizlik hissini onarmakta; kader inancı ile birlikte Yüce kudrete teslimiyet, dindarlığın rehabilite edici fonksiyonu ortaya çıkarabilmektedir.

\section{Tablo 7. Hem Belirlenmiş Hem de Yönlendirilebilen Olgu Olarak Kader Teması}

\begin{tabular}{|c|c|c|}
\hline & Nitelik Bağlamında Kader & Metaforlar \\
\hline & $\begin{array}{l}\text { Hem Belirlenmiş Hem de } \\
\text { Yönlendirilebilen Olgu } \\
\text { Olarak Kader }\end{array}$ & $\begin{array}{l}\text { Senaryo, Tiyatro, Yol (3), Sınırları belirleyen tel, Süpürge, Kitap (3), } \\
\text { Yol ayrımı, Çark, Otobüs şoförü, Günlük, Güneş, Freni tutmayan } \\
\text { araba, Harita, Lamba, Terazi, Belirlenmiş rotada kaybedilmiş adres, } \\
\text { Kapitalizm, Hapishane, Kaptanın dümende olduğu dalgalı deniz, } \\
\text { Film. }\end{array}$ \\
\hline 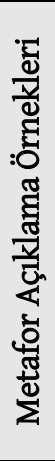 & \multicolumn{2}{|c|}{$\begin{array}{l}\text { "Kader yol gibidir. Çünkü insan olumlu ya da olumsuz gideceği yolu seçer fakat yazı anlamında } \\
\text { önceden yazılmıştır." (K, 23, Niğde Ömer Halisdemir Ü., İslami İlimler F., 9) } \\
\text { "Kader, belirlenmiş rotada kaybedilmiş adres gibidir. Çünkü oraya varacaksın ama hangi yolla } \\
\text { olacağına sen karar vereceksin." (K, 18, Yakındoğu Ü., Eczacıllk F., 7) } \\
\text { "Kader freni tutmayan araba gibidir. Çünkü ne yaparsan yap onu durduramazsın. O yol almaya devam } \\
\text { eder belki ama direksiyon her zaman senin elindedir.” (K, 22, AYBÜ Beslenme ve Diyetetik, 7) } \\
\text { "Kader kitap gibidir. Çünkü bizim ömür boyunca yaptıklarımız ve tercihlerimiz Tanrı tarafından } \\
\text { bilinerek buraya yazılmıştır ve vakti geldiğinde okur gibi yaşarız." (K,20, AKÜ Psikoloji, 6) } \\
\text { "Kader bir otobüs şoförü gibidir. Çünkü varması gereken yer belli fakat yolda mola verdiği mekânlar, } \\
\text { kullanmak istediği yol kendi tercihine kalmı̧tır." (K, 21, Sağlık Bilimleri Üniversitesi, Beslenme ve } \\
\text { Diyetetik, 7) }\end{array}$} \\
\hline
\end{tabular}

Tablo 7'de bazı katılımcıların "kaderin önceden belirlenmiş ya da Allah tarafından bilinen tarafları olsa da insanın eylemlerinde özgür olduğu" düşüncesine dayanan metaforlar ürettikleri

78 Spilka vd., "Din Psikolojisi Açısından Genel Bir Atıf Teorisi”, 173.

79 Doğan, Acıdan Erdeme Yolculuk, 117-118. 
görülmektedir. Her ne kadar insanın eylemlerini seçme konusunda özgürlüğü bulunsa da fizikî ve sosyal çevresinden bağımsız olduğu düşünülemez. Düzgün bu konuda insanın dünyaya geldiğinde insani özelliklerini ve çevresindeki varlık âlemini ve bu âlemin niteliklerini hazır bulduğunu, kendi fıtratını ve dış dünyayı kullanmaya başladığında insanın iradesi, seçimleri ve kararlarının değer kazandığını, sorumluluğunun sınırlarının belirginleştiğini belirtmektedir. ${ }^{80}$ Lise öğrencileri ile gerçekleştirilen araştırmada da katılımcıların \%21,5'i kendi kaderini çizebileceğini, \%64,9'u kendisine verilen akıl ve irade sayesinde kaderine bir miktar yön verebileceğini fakat elinde olmayan durumların olduğunu, \% 13,6'sı kişisel çaba ile alnına yazılmış kaderin değişmeyeceğine inandığını belirtmiş̧ir. ${ }^{81}$

Bu metaforları oluşturan bireylerin Ehl-i sünnet kader anlayışına yakın bir görüşe sahip oldukları söylenebilir. Zira "bireyin önceden belirlenmiş özellikleri yanında seçme özgürlüğü de vardır ve onun neyi seçeceği Yüce Allah'ın sınırsız ilmi ile bilindiğinden Levh-i mahfuzda yazılıdır” inancı Müslümanlar arasında yaygın bir inançtır. Okullarda din eğitimi derslerinde kader inancı genellikle bu çerçevede anlatılır. Bu metaforları üreten bireylerin genellikle içsel kontrol odağına sahip, karşılaştıkları problemleri aktif bir şekilde çözmeye ve sorumluluk yüklenmeye istekli bireyler oldukları, kader algılarının psikolojik iyi oluşlarına olumlu yansıyacağı söylenebilir. Bu bağlamda yapılan bir araştırmada Ehl-i sünnet kader algısının psikolojik sağlığı koruyucu etkisinin olduğu belirlenmiştir. ${ }^{82}$

\section{Tablo 8. Savunma Mekanizmas1 Olarak Kader Teması}

\begin{tabular}{|c|c|c|}
\hline \multicolumn{2}{|c|}{ Nitelik Bağlamında Kader } & \multirow{2}{*}{$\begin{array}{l}\text { Metaforlar } \\
\text { Günah Keçisi, Liman (2), Sığınak (3), Yol, Küçük bir çocuğa } \\
\text { verilen şeker. }\end{array}$} \\
\hline & $\begin{array}{l}\text { Savunma Mekanizması Olarak } \\
\text { Kader }\end{array}$ & \\
\hline & \multicolumn{2}{|c|}{$\begin{array}{l}\text { "Kader günah keçisi gibidir. Çünkü insanlar iyi olan fiillerini ve başına gelen iyi olayları kendinde } \\
\text { toplarken kötü olanlarını ise kaderin üstüne atar." (E, 23, AKÜ İslami İlimler F., 5) } \\
\text { "Kader sığınak gibidir. Çünkü insanlar yaptıkları şeylerin sorumluluğunu almak istemediğinden } \\
\text { kadere sığınır.” (K, 18, İÜ Matematik Mühendisliği, Herhangi bir dine inanmıyor) } \\
\text { "Kader sığınılacak liman gibidir. Çünkü değiştirilemeyen olaylarda kadere sığınmak insanın } \\
\text { psikolojisini korur." (E, } 21 \text { Ankara Ü. Hukuk F., 2) } \\
\text { "Kader sığınak gibidir. Çünkü kaçmak istediğimizde, işimize gelemeyen durumlarda içinde } \\
\text { kaybolmak isteriz." (K, 20, AYBÜ Beslenme ve Diyetetik, 4) }\end{array}$} \\
\hline
\end{tabular}

Tablo 8'de görüldüğü gibi bazı katılımcılar kaderi bireylerin sığındığı savunma mekanizması olarak nitelendirdiklerini gösteren metaforlar üretmişlerdir. Bulgular incelendiğinde görülmektedir ki bu bireyler arasında kaderin bir savunma mekanizması olarak kullanılmasını eleştirenlerin yanı sıra onu güvenli bir liman olarak görenler de bulunmaktadır. Dolayısıyla katılımcıların bazısının oluşturdukları metaforlarla dinin teselli etme fonksiyonunu öne çıkardıkları söylenebilir.

80 Düzgün, “Kader'i Farklı Kategoriler İçinde Okumanın İmkanı”, 5.

81 Saffet Kartopu, "Kaygının Kader Algıları İle İlişkisi-(Kahramanmaraş Örneği)”, Gümüşhane Üniversitesi İlahiyat Fakültesi Dergisi 2/3 (Haziran 2013), 251.

82 Karaca, "Kader Algısı -Ruh Sağlığı İlişkisi Üzerine Empirik Bir Araştırma”, 489. 


\section{2. İnanç Özgürlük Bağlamında Kader}

\section{Tablo 9. Fatalist Eğilimli Kader Olgusu Teması}

\begin{tabular}{|c|c|c|}
\hline & $\begin{array}{l}\text { İnanç-Özgürlük Bağlamında } \\
\text { Kader }\end{array}$ & Metaforlar \\
\hline & Fatalist Eğilimli Kader Olgusu & $\begin{array}{l}\text { Kapalı kutu, Ferman, Alınyazısı, Rüzgar, Saat, Yol (3), } \\
\text { Günah Keçisi, Gemi, Piyango, Pusula, Ağaçtaki yaprak, } \\
\text { Zorunluluk, Su, Harita (2), Gökyüzü, Geçmişim, } \\
\text { Navigasyon, Hikaye, Film, Zaman makinası, Güneş (2), } \\
\text { Labirent (2), Çark (2), Çizgi (2), Şans, Kontrol edilemeyen } \\
\text { kuş, Asansör, Akan derede yüzmek, Mahkumluk, Dipsiz } \\
\text { kuyu, Tükenmez kalem, Senaryo, Belirsizlik, Kontrolsüz } \\
\text { hortum, Baba-anne, Zaman, Hapishane, Hediye Paketi }\end{array}$ \\
\hline 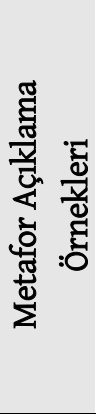 & \multicolumn{2}{|c|}{$\begin{array}{l}\text { “Kader serim kısmı belli, düğüm ve çözümü belli olmayan bir hikaye gibidir. Çünkü hayatımızın başı } \\
\text { bellidir ama yaşayacağımız geri kalan hayatımızı kaderimiz belirler." (K, 20, AYBÜ, Sosyal Hizmet, 3) } \\
\text { "Kader kontrol edilemeyen kuş gibidir. Çünkü sen onu belli bir yöne uçurtmak istesen bile o kendi } \\
\text { kanatlarıyla özgürce istediği yönde ilerler." (K, 26, Bilkent Ü., Iç̧ Mimarlık Çevre Tasarımı, 7) } \\
\text { "Kader labirent gibidir. Çünkü hangi yola sapsak çıkış bir tanedir, biz içinde oyalanıp dururuz." (K, 24, } \\
\text { Bilkent Ü. Mimarlık, 4) } \\
\text { "Kader değişmez bir senaryo gibidir. Çünkü başımıza ne geleceği önceden planlanmıştır bize sadece } \\
\text { kendi rolümüzü oynamak düşer." (K, 20, AKÜ Psikoloji, 3) } \\
\text { "Kontrolsüz bir hortumdur. Çünkü senin iraden dışı seni sürükler.” (E, 29, AKÜ Devlet Konservatuarı, } \\
\text { 7) }\end{array}$} \\
\hline
\end{tabular}

Tablo 9'da bazı katılımcıların oluşturdukları metaforlar, fatalist eğilimli bir kader algısına işaret etmektedir. İnanç- özgürlük kategorisi altında yer alan bu metaforları üreten katılımcılar, insanların kendi hayatlarında tasarruf yetkilerinin olmadığını, adeta etkisiz bir özne olduklarını anlatmak istemişlerdir. Bulgulardan katılımcıların dörtte birinden fazlasının kadere ilişkin görüşlerinin fatalist eğilimli olduğu çıkarılabilir. Bu bireylerin hayat problemleri karşısında sıklıkla pasif tutumu tercih edecekleri, kişilik olarak dışsal kontrol odağına sahip olup hayatları ile ilgili sorumluluk yüklenmeye isteksiz olacakları söylenebilir. Ülkemizde yapılan uluslararası karşılaştırmalı bir araştırmada katılımcılara hayatın kendi aldıkları kararlar ve yaptıkları dışında belirlenip belirlenmediği sorusu yöneltilmiş, katılımcıların \% 50'ye yakını hayatın akışını değiştirebilmek için yapılabilecek çok az şey olduğuna inandığını, yalnızca \%28'i hayatlarını değiştirebileceklerine inandığını belirtmişlerdir. ${ }^{83}$ Cezaevi mahkumlarıyla yapılan bir araştırmada da katılımcıların yarıya yakınının insanın kaderini değiştirmesinin mümkün olmadığını düşündükleri belirlenmiştir. ${ }^{84}$

** Araştırmada inanç temelli kader olgusu teması altında yer alan metaforların bazısının kendisinde ve açıklamalarında dinî bir kavram kullanılmamıştır fakat katılımcıların kader denildiğinde akıllarına ilk gelen kavramlar arasında "Allah, takdir, tevekkül, levh-i mahfuz, teslimiyet, din, iman" gibi kavramları sıralamaları, onların kaderi inançla ilişkilendirdikleri şeklinde yorumlanmıştır.

83 Ali Çarkoğlu - Ersin Kalaycıŏlu, Türkiye'de Dindarlk: Uluslararası bir Karşlaştırma (İstanbul: Sabancı Üniversitesi İstanbul Politikalar Merkezi, 2009), 7.

84 Yusuf Katırcı, Cezaevi Mahkumlarının Kader Anlayışı: Ferizli L Tipi Cezaevi Örneği (Sakarya: Sakarya Üniversitesi, Sosyal Bilimler Enstitüsü, Yüksek Lisans Tezi, 2011), 61. 


\section{Tablo 10. İnanç Temelli Kader Olgusu Teması}

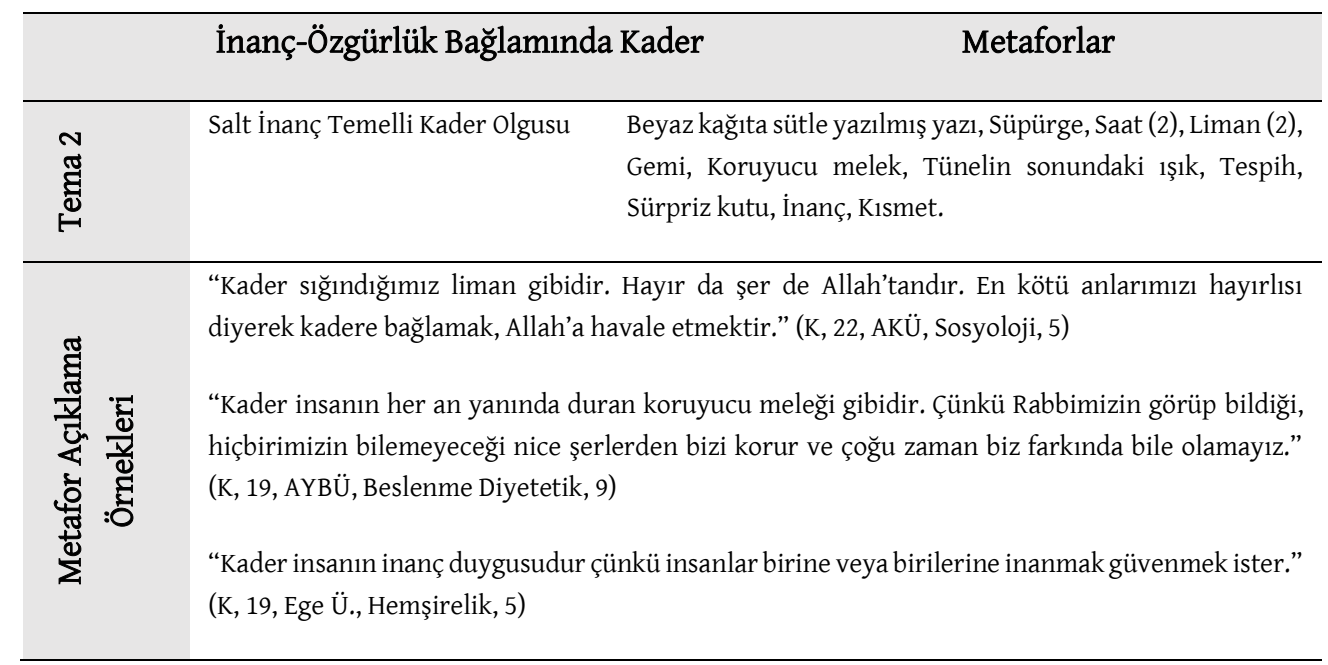

Tablo 10'da yer alan metaforları oluşturan katılımclar kaderi inançla ilişkilendirmişler fakat insanın eylemlerinde özgür olup olmadığı konusuna temas etmemişlerdir. Bu bireylerin kaderi sadece inanç merkezli ele aldıkları, bir inanç esası olarak kabul ettikleri, zihinlerinde kaderle ilgili herhangi bir problemin olmadığı söylenebilir. Ayrıca metaforların açılamalarına bakılarak katılımcıların hayat problemleri karşısında sıklıkla Allah'a teslimiyeti tercih ettikleri söylenebilir. Benzer şekilde yapılan bir araştırmada dinsel inançlar ile "Allah" ve "kader" kavramları arasında olumlu ilişki tespit edilirken "talih" kavramı arasında olumsuz ilişki belirlenmiştir. Allah ve kader etkenleri arasında da güçlü ve anlamlı bir ilişki tespit edilmiştir. ${ }^{85}$

\section{Tablo 11. İnanç Temelli İradeci Kader Olgusu Teması}

\begin{tabular}{|c|c|c|}
\hline & \multicolumn{2}{|c|}{ İnanç-Özgürlük Bağlamında Kader } \\
\hline & İnanç Temelli İradeci Kader Olgusu & $\begin{array}{l}\text { Yolculuk, Tiyatro, Baba-evlat, Araba kullanmak, Hamur, } \\
\text { İp cambazının ipin üzerinde yürümesi, Kaya, Roman, } \\
\text { Kalem, Otobüs Şoförü, Matematikteki bilinmeyen X, Yol } \\
\text { (7), Kitap (2), Ayna, Kum saati, Çoktan seçmeli sınav, Çok } \\
\text { bilinmeyenli denklem, Lamba, Tercih sonuçları, Tohum, } \\
\text { Terazi, Yol ayrımı, Akarsu, Senaryo, Çark, Sınırları } \\
\text { belirleyen tel. }\end{array}$ \\
\hline 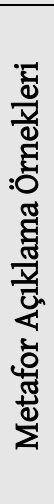 & \multicolumn{2}{|c|}{$\begin{array}{l}\text { "Kader araba kullanmak gibidir. Çünkü nasıl ki arabaya yön veren kişinin kendisi ise kaderde de } \\
\text { böyledir." (K, 24, AKÜ İslami İlimler F., 4) } \\
\text { "Kader meselesi baba ve evlat arasındaki ilişki gibidir. Çünkü baba evladına hayat karşısında } \\
\text { nasihatler vererek onun kararları doğrultusunda olabilecekleri anlatır, fakat tercih hakkı çocuğa } \\
\text { aittir." (E, 23, Okan Ü., Hukuk F., 10) } \\
\text { "Kader bir kitap gibidir. Çünkü o kitabı almısşak okuruz. Allah'ın yazdıklarını değiştiremeyiz ama } \\
\text { seçimlerimiz bizim elimizdedir." (K, 19, AYBÜ, Sosyal Hizmet, 8) } \\
\text { "Kader tohum gibidir. Çünkü ne ekersen onu biçersin. Kader çalışmaya, çabaya, hedefe bağlıdır } \\
\text { karşllığını alırsın." (E, 18, Lokman Hekim Ü., Diyaliz, 9) } \\
\text { "Kader seçimlik haklarımız olan bir senaryo gibidir. Çünkü Allah Külli iradesiyle bizim hayatımızı } \\
\text { genel itibariyle belirlemiştir ancak hayatımızın tamamını belirlememiştir. Hayatımızdaki iyi veya } \\
\text { kötü şeyleri biz cüz'î irademizle seçerek belirliyoruz." (E, 20, AKÜ, Hukuk F., 6) }\end{array}$} \\
\hline
\end{tabular}

85 Yaparel, “Depresyon ve Dinî İnançlar ile Tabiatüstü Nedensel Yüklemeler Arasındaki İlişkiler”, 290. 
Tablo 11'de kaderi zihinlerinde bir inanç olgusu olarak kodlamış, ona daha çok dinî anlam yükleyen katılımcıların oluşturdukları metaforlar görülmektedir. Bu metaforların bazısının açıklamalarında dini ifadeler kullanılmamışsa da kaderle ilişkili kavram sıralamasında "Allah, takdir, tevekkül, cüz’i irade” gibi kavramlara yer verdikleri görülmüştür. Metaforlarda insanın seçme özgürlüğüne yapılan vurgu, inanç temelli iradeci kader olgusu temasını ortaya çıkarmıştır. Bu bireylerin içsel kontrol odağına sahip oldukları, karşılarına çıkan hayat problemlerini çözme yönünde irade sergileyecekleri, sorumluluk yüklenecekleri, dinî bir tutum olarak da yerine göre tevekkülü veya Allah'a teslimiyeti seçecekleri söylenebilir.

\section{Tablo 12. İnanç Temelli Cebrî Kader Olgusu Teması}

\begin{tabular}{|c|c|c|}
\hline \multicolumn{2}{|r|}{$\begin{array}{l}\text { İnanç-Özgürlük } \\
\text { Bağlamında Kader }\end{array}$} & Metaforlar \\
\hline 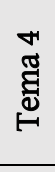 & İnanç Temelli Cebrî Kader Olgusu & $\begin{array}{l}\text { Tasma, Harita, İrademizin üstünde güç, Yaydan çıkmış ok, } \\
\text { Müteşâbih âyetler, Gölge, Yol ayrımı, Yol (3), Kalem, Nehir, } \\
\text { Labirent, Kitap, Hayatın odağı, Zaman (2), Plan, Değişmeyen } \\
\text { kanun. }\end{array}$ \\
\hline 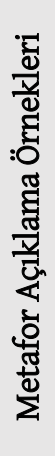 & $\begin{array}{l}\text { "Kader uzun ve çetrefilli bir yol gi } \\
\text { olarak belirlenmiş gelecek, bekle } \\
\text { eğmemizi emreden bir olgu." (K, } 21 \\
\text { "Kader bir nehir gibidir. Çünkü eni } \\
\text { F., 8) } \\
\text { "Kader kitap gibidir. Çünkü so } \\
\text { Rehabilitasyon, 6) } \\
\text { "Elimizden akıp giden zaman gibic } \\
\text { ilminin neticesidir, mukadderattır. } \\
\text { "Kader, deftere yazılan, değişmeye } \\
\text { yazılan değişmeyendir." (K,21, AKÜ }\end{array}$ & $\begin{array}{l}\text { idir. Çünkü ilerleyerek yeni ve farklı şeylerle karşılaşırız. İlahi } \\
\text { amedik bir şekilde ilerleyen ve son bulan, olanlara boyun } \\
\text { AYBÜ, Sosyal Hizmet, } 5) \\
\text { de sonunda olması gereken yere ulaşır." (K, 24, Atatürk Ü., Tıp } \\
\text { unu sen değiştiremezsin." (K, 21, AYBÜ Fizyoterapi ve } \\
\text { ir. Çünkü kader, bizim elimizde olan bir şey değildir, Allah'ın } \\
\text { (K, 20, AYBÜ, Dil ve Konuşma terapisti, 6) } \\
\text { kanunlar gibidir. Çünkü kader kişinin alnına Allah tarafından } \\
\text { Sosyoloji, 7) }\end{array}$ \\
\hline
\end{tabular}

Tablo 12'deki metaforlardan bazı katılımcıların kaderi inanç konusu olarak değerlendirmekle birlikte yaşanacakların Allah tarafından belirlendiğine ve değişmeyeceğine işaret ettiklerinden cebrî kader anlayışını temsil ettikleri görülmektedir. Bu bireylerin dışsal kontrol odağına sahip oldukları, başlarına gelenlerin nedenleri konusunda sorumluluk üstlenmeyip dışal faktörlere bağlamaya eğilimli olacakları, başarılı olmak için çaba göstermekten kaçınacakları, inanç bakımından ise yaşananları Allah'a havale ederek teslimiyeti ve eylemsizliği tercih edecekleri söylenebilir. ${ }^{86}$ Bu yaklaşım psikolojik iyi oluşu da olumsuz etkileyebilir. Zira farklı yaş grupları ve mesleklerden bireylerle yapılan bir araştırmada cebrî kader algısına sahip katılımcıların kader inançları ile yaşamın amacı ve bireysel gelişim boyutu başta olmak üzere psikolojik iyi oluş düzeyleri arasında negatif yönlü anlamlı ilişkiler bulunmuştur. ${ }^{87}$

86 Coşkun, “Engellilik-Kader İlişkisi ve Genom Projesi İle Bu İlişkinin Geleceğine Dair Tartışmaların Değerlendirilmesi”, 76.

87 Nurun Nisa Kilit, Kader Algısı-Psikolojik L̇yi Oluş İlişkisi Üzerine Bir Araştırma (Erzurum: Atatürk Üniversitesi, Sosyal Bilimler Enstitüsü, Yüksek Lisans Tezi, 2019), 111. 


\section{Tablo 13. İnanç Temelli Olmayan İradeci Kader Olgusu Teması}

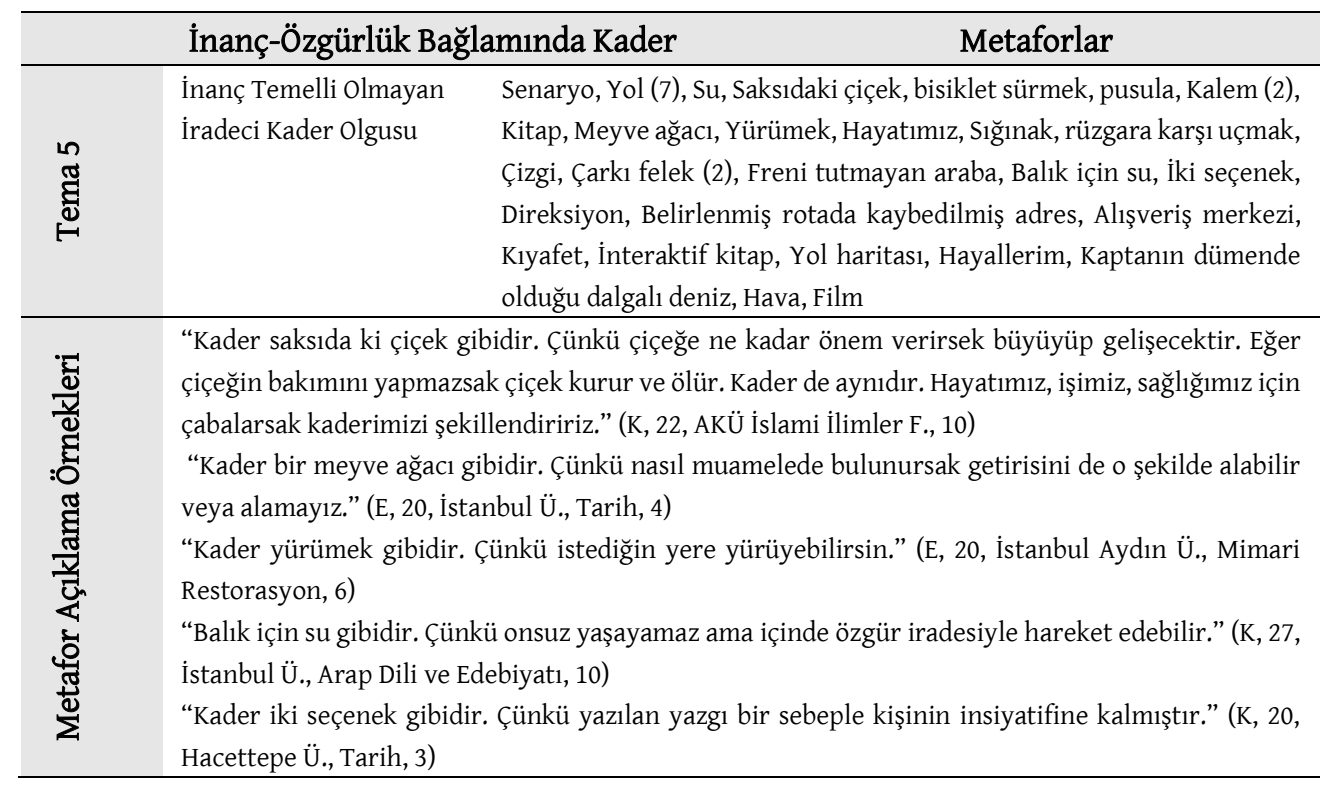

Tablo 13'te bazı katılımcıların ne oluşturdukları metaforlarda ne de kader denince akıllarına gelen kavramlarda dinle ilişkili ifadelere yer vermedikleri fakat metaforların açıklamalarında insanın eylemlerindeki seçme özgürlüğüne işaret ettikleri görülmektedir. Bu bireylerin kaderi bir dinî inanç konusu olmaktan ziyade yaşamsal bir olgu olarak gördükleri söylenebilir. Kaderin önceden belirlenmiş olduğuna ilişkin herhangi bir atfın da bulunmadığı bu metaforları oluşturan katılımcıların insan iradesine önem verdikleri, içsel denetim odağına sahip olup sorunlarıyla başa çıkarken genellikle kendi içsel güçlerine dayandıkları söylenebilir.

\section{Tablo 14. Kader Karşıtı Algı Teması}

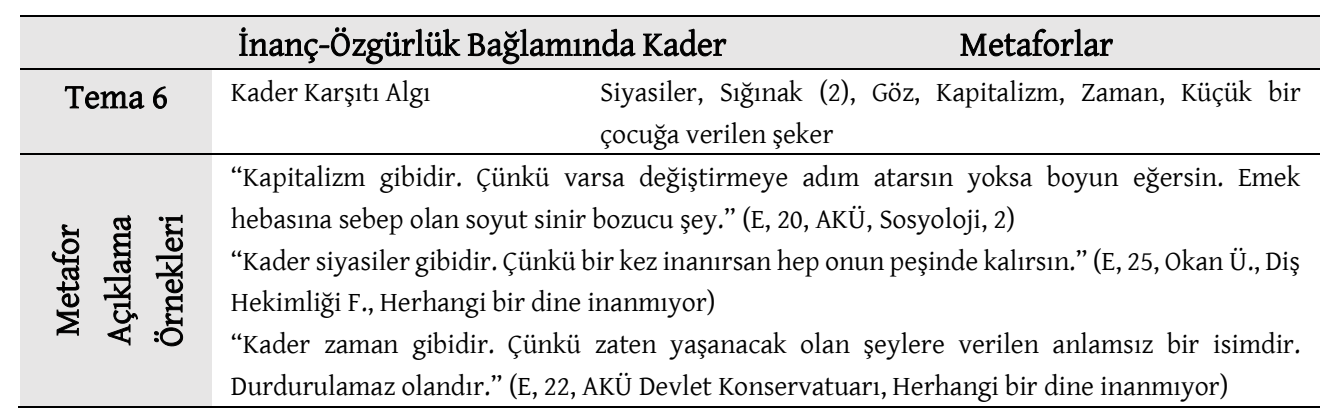

Katılımcılar içerisinde küçük bir grubun negatif anlam yükledikleri kaderi yaşamsal bir olgu olarak değerlendirerek karşıt bir tutum sergiledikleri, Tablo 14'teki metaforlardan anlaşılmaktadır. Bu metaforların açıklamalarında dinle ilişkilendirme yapılmadığı gibi kaderin bireyi pasifleştirdiği, bahane olarak kullanıldığı, boyun eğmeye neden olduğu gibi görüşlere yer verilmiştir. Bu bireylerin kederi başa çıkma veya atıf/yükleme enstrümanı olarak kullanmayı tercih etmeyecekleri söylenebilir. 


\section{Sonuç}

Kader, insan hayatını doğrudan ilgilendirdiğinden her dönem ilgi çekici konular arasında yer almıştır. Kaderin bilinmeyen yönleri ve kaderle ilgili belirsizlikler, insanın merak duygusunu daima canlı tutan bir unsur olmuştur. İnsanların inançları hayat perspektiflerini belirlemede önemli bir unsur olmakla birlikte kader inancının "insanın iradesi, seçme özgürlüğü, sorumluluğu" gibi konuları içermesi nedeniyle davranışları etkileme potansiyelinin diğerlerinden bir adım önde olduğu söylenebilir. Dolayısıyla kader algısı, bireylerin hayata karşı tutum belirlemesinde referans noktasını oluşturmaktadır. ${ }^{88}$ Kader algılarının insan davranışlarını etkileme gücü, araştırmanın konusunun belirlenmesinde etkili olmuştur. Üniversite öğrencilerinin kader algılarını konu alan bu araştırma, fenomenolojik olgu bilim yöntemine dayalı metafor analizi tekniğiyle gerçekleştirilmiştir. Kaderle ilgili doğrudan sorular sormak yerine bu yöntemin tercih edilmesinin nedeni gençlerin zihinlerinin derinliklerinde yer alan gerçek düşüncelerine ulaşmaktır. Bu çerçevede gerçekleştirilen inceleme sonucunda araştırmanın soruları çerçevesinde bazı önemli sonuçlar tespit edilmiştir. Kaderle ilgili tartışmalar, daha çok kaderin önceden belirlenmiş olup olmaması ve insanın kendi kaderi üzerindeki etkisi konularına odaklanmaktadır. Bu bağlamda araştırmada bazı katılımcıların metafor üretirken kaderle ilgili problemlerin zihinlerindeki karşılıklarına açıklık getirmeye çalıştıkları ve kavramsal olarak kaderi tanımlamaya çalıştıkları belirlenmiştir.

Araştırmaya katılan üniversite öğrencilerinin "kader" kavramına ilişkin 106 metafor ürettiği araştırmada en sık tekrarlanan metaforun "Yol" metaforu olduğu, bunu "kitap" ve "çark" metaforlarının izlediği tespit edilmiştir. "Senaryo, kalem, harita, yol ayrımı, sığınak, çizgi, gemi”" metaforları ise en fazla tercih edilen ilk on metaforun içindedir. 87 metaforun ise bir kez tekrarlandığı görülmüştür (bk. Tablo 2).

Araştırma kapsamında üretilen metaforların açıklamaları incelenmiş, ortak özellikleri bakımından gruplandırılmış, temalar oluşturulmuş, temalar da kendi aralarında gruplandırılarak kategoriler oluşturulmuştur. Kategorilerden birine nitelik bağlamında kader, diğerine ise inançözgürlük bağlamında kader ismi verilmiştir. Nitelik bağlamında kader kategorisinin alt temalarına bulgulardan hareketle "değişmeyen/belirlenmiş, yönlendirilebilen/tercih edilebilen, bilinmeyen/kontrol edilemeyen, hem belirlenmiş hem de yönlendirilebilen olgu olarak ve savunma mekanizması olarak kader" ismi verilmiştir. İnanç-özgürlük bağlamında kader kategorisinin alt temaları ise "fatalist eğilimli, salt inanç temelli, inanç temelli iradeci, inanç temelli cebrî, inanç temelli olmayan iradeci kader olgusu ve kader karşıtlı̆̆ı"dır (bk. Tablo 3).

Araştırmada üniversite öğrencilerinin nasıl bir kader algısına sahip olduklarını ortaya koymak için metaforlar incelenmiş, öncelikle katılımcıların geliştirdikleri metaforlarla insanın kendi kaderindeki etkisine odaklandıkları görülmüştür. Bu bağlamda öğrencilerin, insanın eylemlerinde özgür olup seçimler yapabildiği düşüncesini içeren metaforların yanı sıra kaderin önceden belirlenmiş olup değiştirilemeyeceği düşüncesini ön plana çıkaran metaforlar geliştirdikleri tespit edilmiștir. Kaderle ilgili eylem özgürlüğüne sahip olup insanın kendi kaderinde söz sahibi

88 Ümit Horozcu, “Teistik Kader Algısı Ölçeği'nin Geliştirilmesi: Güvenirlik ve Geçerlik Çalışması”, Darulfunun ìlahiyat 29/1 (Haziran 2018), 12. 
olduğunu düşünenler çoğunlukta olsa da araştırmada kaderin önceden belirlenmiş olup bilinmeyen, kontrol edilemeyen, değiştirilemez bir olgu olduğu düşüncesinin önemli oranda varlığının belirlenmiş olması, öğrencilerin zihinlerinde kader konusunda bir bulanıklığın olduğunu göstermektedir. Bu görüşlerin toplumun genel kabulüyle örtüştüğünü söylemek yanlış olmayacaktır. Gençlerin kader algılarındaki negatif unsurları sosyal etkileşim yoluyla kazandıkları, toplumda var olan kalıplaşmış yorumlardan etkilendikleri söylenebilir.

Katılımcıların kader algılarındaki önemli bir husus da kaderi bir inanç konusu olarak değerlendirip değerlendirmedikleridir. Araştırmada katılıcıların \% 40'a yakını kaderi dinle ilişkilendirdiklerini, inanç temelli bir kader algısına sahip olduklarını oluşturdukları metaforlarla göstermişlerdir. Diğer katılımcıların ise gerek oluşturdukları metaforlar gerekse kaderle ilişkili kelime seçimleri, kaderi bir inanç olgusu değil yaşamsal bir olgu olarak değerlendirdiklerini göstermektedir. Bunların arasında insanın davranışlarında özgür olduğunu, hayatını kendisinin yönlendirdiğini vurgulayan önemli bir kesim (\%22) olmakla birlikte fatalistik eğilim dikkat çekmektedir. Öğrencilerin dörtte birinden daha fazlasının (\%27) oluşturdukları metaforlarda fatalistik unsurlara rastlanmıştır. Fatalistik eğilimli olanlar arasında yüksek din öğretimi öğrencilerinin de yer alması (\%1,8), kader algılarının oluşumunda toplumdaki kalıplaşmış yargıların ne kadar etkili olduğunu göstermesi bakımından oldukça dikkat çekicidir. Bulgulardan yola çıkarak inanç temelli kader algısına sahip olan katılımcıların kaderi, yaşadıklarını anlamlandırırken dinî yükleme aracı olarak, sorunlarıyla başa çıkarken dini başa çıkma aracı olarak kullanabilecekleri söylenebilir. Ancak kaderi dinle ilişkilendirmeyen ve insan özgürlüğüne atıf yapan katılımcıların kader inancını daha az dini yükleme ve dini başa çıkma aracı olarak kullanabileceklerinden söz edilebilir. Diğer taraftan fatalistik eğilimli ya da cebri kader algısına sahip olan katılımcılar kaderi nedensel anlamlandırma, başa çıkma ve savunma mekanizması olarak kullanabilir; kaderin teselli edici, rahatlatıcı fonksiyonlarından kısmen yararlanabilirler. Fakat fatalistik tutum problem çözücü olmadı̆̆ından ve pasifliğe, umutsuzluğa, öğrenilmiş çaresizliğe neden olduğundan bu bireylerin kader algılarının problemleriyle etkili bir başa çıkmayı sağlayamayacağı, hayatta başarısızlığa yol açacağı söylenebilir. Ayrıca psikolojik sağlıklarının da bu tutumlarından olumsuz etkileneceği tahmin edilebilir.

Araştırma, gençlerdeki fatalistik eğilimin hiç de küçümsenemeyecek boyutlarda olduğunu göstermiştir. Bu sonuç kader algısının oluşumuna etki eden eğitim faktörünün özellikle de ders kitaplarının dikkatle gözden geçirilmesinin gerekliliğini ortaya koymaktadır. Zira din eğitimi ders kitaplarındaki açıklamalardaki belirsizlik ve yetersizlikler, kader konusunu gençlerin zihninde daha bulanık hale getirebilir. Sağlıklı kader algısının oluşmasında öğretmen faktörü de önemli olduğundan, öğretmen yetiştiren kurumların bu eğitiminin nasıl olması gerektiği hususuna önemle eğilmeleri gerekmektedir. Zira karakteristik bir özellik olarak bilgiyi rasyonelleştirme çabası bilinen ergenler için kader bir inanç problemi oluşturabileceği gibi son yıllarda inançla ilgili gençlerdeki farklı yönelimlerin temelinde bu problemler yatıyor olabilir. Bu bağlamda din eğitimi alanında yapılacak "kader eğitimi" konulu akademik çalışmaların sorunun çözümüne katkı sağlayacağı düşünülmektedir. 


\section{Kaynakça}

Akbulut, Ahmet. Sahabe Dönemi İktidar Kavgası-Alevi Sünni Ayrışmasının Arka Planı. Ankara: Otto Yayınları, 5. Basım, 2017.

Atay, Hüseyin. Kur'an'da İman Esasları ve Kader Sorunu. Ankara: Atay Yayınları, 2013.

Aydın, Cüneyd. "Kader İnancının Savunma Mekanizması ve Dinî Başa Çıkma Kavramları Açısından Değerlendirilmesi”. Hitit Üniversitesi İlahiyat Fakültesi Dergisi 18/35 (2019), 101-122.

Batman, Elif. Yaşamın Zorluklarılla Başa Çıkmada Kader İnancının Rolü. Adana: Çukurova Üniversitesi Sosyal Bilimler Enstitüsü, Yüksek Lisans Tezi, 2008.

Baymur, Feriha. Genel Psikoloji. İstanbul: İnkılap Yayınevi, 8. Basım, 1989.

Bjorck, Jeffrey P. - Cohen, Lawrence H. "Coping With Threats, Losses and Challenges". Journal of Social and Clinical Psychology 12/1 (1993), 56-72.

Bolay, Süleyman Hayri. Felsefi Doktrinler Sözlüğ̈̈. Ankara: Akçağ Yayınları, 1987.

Budak, Selçuk. Psikoloji Sözlüğü. Ankara: Bilim ve Sanat Yayınları, 2017.

Bulut, İsmail. "Kader-Engellilik İlişkisine Kelami Bir Yaklaşım”. Atatürk Üniversitesi İlahiyat Fakültesi Dergisi 43 (2015), 20-51.

Büyüköztürk, Şener vd. Bilimsel Araștırma Yöntemleri. Ankara: Pegem Yayınları, 17. Basım, 2014.

Cengiz, Lütfü. "Emeviler Döneminde Kader Problemi”. Marife Din̂̂ Araştırmalar Dergisi 1/2 (Ekim 2001), 107-127.

Coşkun, İbrahim. “Matürîdî Düşüncede Allah-İnsan İlişkisi”. Hikmet Yurdu 2/4 (2009), 17-46.

Coşkun, İbrahim. "Engellilik-Kader İlişkisi ve Genom Projesi İle Bu İlişkinin Geleceğine Dair Tartışmaların Değerlendirilmesi “. I. Uluslararası Engellilik ve Din Sempozyumu. İstanbul: Yeditepe Ofset Yayıncilik, 2016.

Coşkun, İbrahim. Günümüz Akaid ve Kelam Problemleri. İstanbul: Kitap Dünyası, 2017.

Çarkoğlu, Ali - Kalaycıŏ̆lu, Ersin. Türkiye'de Dindarlk: Uluslararası bir Karşılaştırma. İstanbul: $\begin{array}{llll}\text { Sabanc1 Üniversitesi İstanbul Politikalar } & \text { Merkezi, }\end{array}$ https://research.sabanciuniv.edu/14014/1/Rapor_Dindarl\%C4\%B1k.pdf

Çelik, Celaleddin. "Teodisenin Sosyolojisi: Toplumsal Süreçlerle İlişkisi İçinde Teodise Konusuna Sosyolojik Bir Yaklaşım”. Bilimname 13/2 (2007), 37-66.

Çiçekler, Ahmet Naim - Aydın, Timur. "Kavramsal Metafor Kuramı ve Belagat: Karşılaştırmalı bir İnceleme”. RumeliDE Dil ve Edebiyat Araştırmaları Dergisi 16 (2019), 14-26.

Dağ, İhsan. Kontrol Odağı, Stresle Başa Çıkma Stratejileri ve Psikolojik Belirti Gösterme İlişkileri. Ankara: Hacettepe Üniversitesi, Sosyal Bilimler Enstitüsü, Doktora Tezi, 1990.

Dağ, İhsan. “Kontrol Odağı Ölçeği (KOÖ): Ölçek Geliştirme, Güvenirlik ve Geçerlik Çalışması”. Türk Psikoloji Dergisi 17/49 (2002), 77-90. 
Doğan, Mebrure. Sabır Psikolojisi- Pozitif Psikoloji Bağlamında Bir Araștırma. İstanbul: Çamlıca Yayınları, 2016.

Doğan, Mebrure. Acıdan Erdeme Yolculuk - Travma Sonrası Gelişim Psikolojisi ve Din. İstanbul: Çamlıca Yayınları, 2. Basım, 2020.

Düzgün, Şaban Ali. “Kader'i Farklı Kategoriler İçinde Okumanın İmkanı”, Kelam Araştırmaları Dergisi 11/2 (2013), 1-10.

Ekşi, Halil. Başaçıkma, Dinî Başaçıkma ve Ruh Sağığı Arasındaki İlişki Üzerine Bir Araştırma. Bursa: Uludağ Üniversitesi, Sosyal Bilimler Enstitüsü, Doktora Tezi, 2001.

Eraslan, Levent. "Sosyolojik Metaforlar”. Akademik Bakış Dergisi 27 (2011), 1-22.

Eren, Hasan vd. Türkçe Sözlük. Ankara: Türk Tarih Kurumu Basımevi, 1988.

Grimal, Pierre. Mitoloji Sözlüğ̈̈ - Yunan ve Roma. çev. Sevgi Tamgüç. İstanbul: Kabalcı Yayınevi, 2007.

Güneş, Aysun - Fırat, Mehmet. "Açık ve uzaktan öğrenmede metafor analizi araştırmaları". Açıöğretim Uygulamaları ve Araștırmaları Dergisi 2/3 (2016), 115-129.

Gürses, İbrahim. "Yükleme Teorisi ve Din İlişkisi Üzerine Bir Değerlendirme”. Uludağ Üniversitesi ilahiyat Fakültesi Dergisi 17/2 (2008), 359-377.

Gorsuch, Richard - Smith, Craig S. "Attributions of Responsibility to God: An Interaction of Religious Beliefs and Outcomes". Journal for the Scientific Study of Religion 22/4 (1983), 340-352.

Gömleksiz, Mehmet Nuri vd. "Sosyal Bilgiler Öğretmen Adaylarının Bir Değer Olarak Demokrasi Kavramına İlişkin Metaforik Algıları”. Değerler Eğitimi Dergisi 10/24 (2012), 79-100.

Hadislerle İslam. ed. Mehmet Emin Özafşar vd. 7 Cilt. Ankara: Diyanet İşleri Başkanlığı Yayınları, 2. Basım, 2013.

Hançerlioğlu, Orhan. İnanç Sözlüğü. İstanbul: Remzi Kitabevi, 1975.

Heider, Fritz. The Psychology of Interpersonal Relationship. New York: Jhon Willey and Sons, 1958.

Horozcu, Ümit. “Teistik Kader Algısı Ölçeği'nin Geliştirilmesi: Güvenirlik ve Geçerlik Çalışması”. Darulfunun İlahiyat 29/1 (Haziran 2018), 9-24.

Hökelekli, Hayati. Din Psikolojisi. Ankara: TDV Yayınları, 3. Basım, 1998.

İbn Manzûr, Muhammed b. Mükerrem. Lisânü'l-'Arab. nşr. Abdullah Ali el-Kebîr. 6 Cilt. Kahire: Dârü'l-Maârif, ts.

İsfahani, Ragıb. Müfredat Elfazi'l Kur'an - Kur'an Kavramları Sözlüğü. çev. Yusuf Türker. İstanbul: Pınar Yayınlar, 2012.

Kağıtçıbaşı, Çiğdem. İnsan ve İnsanlar. İstanbul: Evrim Matbaası, 9. Basım, 1996.

Karaca, Faruk. “Kader Algısı -Ruh Sağlığı İlişkisi Üzerine Empirik Bir Araştırma”. İslami Araştırmalar Dergisi 19/3 (2006), 479-489.

Karaca, Faruk. Din Psikolojisi. Trabzon: Eser Ofset, 2017. 
Karaırmak, Özlem - Güloğlu, Berna. “Metafor: Danışan ve Psikolojik Danışman Arasındaki Köprü”. Türk Psikolojik Danışma ve Rehberlik Dergisi 4/37 (2012), 122-135.

Kartopu, Saffet. "Kaygının Kader Algıları İle İlişkisi-(Kahramanmaraş Örneği)". Gümüşhane Üniversitesi İlahiyat Fakültesi Dergisi 2/3 (Haziran 2013), 238-260.

Kartopu, Saffet. "Psikolojik Açıdan Kadere İman Nedir Ne Değildir?”. Kader Nedir? Ne Değildir?. ed. Adnan Demircan. Ankara: Fecr Yayınları, 2019.

Katırcı, Yusuf. Cezaevi Mahkumlarının Kader Anlayışı: Ferizli L Tipi Cezaevi Örneği. Sakarya: Sakarya Üniversitesi, Sosyal Bilimler Enstitüsü, Yüksek Lisans Tezi, 2011.

Kaya, Alim - Bozkur, Binaz. "Kadercilik Eğilimi Ölçeğinin Geliştirilmesi: Geçerlik ve Güvenirlik Çalışması”. Mersin Üniversitesi Eğitim Fakültesi Dergisi 11/3 (2015), 935-946.

Kaya, Alim - Bozkur, Binaz. "Kadercilik Eğilimi İle Özyeterlik İnancı ve Savunma Mekanizmaları Arasındaki İlişkinin İncelenmesi”. Ege Eğitim Dergisi 18/1 (2017), 124-145.

Keskiner, Emine. "Din Kültürü ve Ahlak Bilgisi Ders Kitaplarındaki Kader Öğretisi Üzerine Bir Değerlendirme”. Düzce Üniversitesi İlahiyat Fakültesi Dergisi 2/2 (2018), 50-65.

Kilit, Nurun Nisa. Kader Algısı-Psikolojik İyi Oluş İlişkisi Üzerine Bir Araştırma. Erzurum: Atatürk Üniversitesi, Sosyal Bilimler Enstitüsü, Yüksek Lisans Tezi, 2019.

Kormanik, Martin B - Tonette S, Rocco. "Internal Versus External Control of Reinforcement: A Review of the Locus of Control Construct". Human Resource Development Review 8/4 (2009), 463-483.

Köse, Ali. Freud ve Din. İstanbul: İz Yayınc1lı, 2.Basım, 2005.

Kur'ân-ı Kerîm Meâli. çev. Halil Altuntaş - Muzaffer Şahin. Ankara: Diyanet İşleri Başkanlığı Yayınları, 3. Basım, 2009.

Lazarus, Richard S. - Folkman, Susan. Stress, Appraisal and Coping. New York: Springer Publishing Company, 1984.

Macit, Mustafa. Boyun Eğme-Başa Çıkma Sarkacında Kadercilik. İstanbul: Ötüken Neşriyat, 2014.

Marshall, Gordon. Sosyoloji Sözlüğü. çev. Osman Akınhay - Derya Kömürcü. Ankara: Bilim ve Sanat Yayınları, 2014.

Orhan, Kamil. "Kadercilik Eğilimi Ölçeği'nin Geçerlik ve Güvenirlik Çalışması". Uluslararası Medeniyet Çalışmaları Dergisi 2 /2 (2017), 83-102.

Özbolat, Abdullah - Kartopu, Saffet. "İsyan ile Teslimiyet Arasında: Ağıtlarda Kader İnancı". Turkish Studies 7/3 (2012), 1959-1972. http://dx.doi.org/10.7827/TurkishStudies.3596

Özcan, Zeynep. "Yükleme, Kaygı ve Başa Çıkma Bağlamında Covid-19 Salgınına Dinî Bakış". Dindarlk, Kişilik ve Ruh Sağlğı. ed. Nevzat Gencer - Muammer Cengil. İstanbul: Çamlıca Yayınları, 2020.

Pargament, Kenneth I. vd. "Religion and the Problem Solving, Process: Three Styles of Coping". Journal for the Scientific Study of Religion 27/1 (1988), 90-104. 
Pargament, Kenneth I. vd. "Patterns of Positive and Negative Religious Coping with Major Life Stressors". Journal for the Scientific Study of Religion 37/4 (1998), 710-724.

Pargament, Kenneth I. “Tanrım Bana Yardım Et: Din Psikolojisi Açısından Başa Çıkmanın Teorik Çatısına Doğru”. çev. Ahmet Albayrak. Tabula-Rasa Felsefe-Teoloji 9 (2003), 207-235.

Pargament, Kenneth I. "Acı ve Tatlı: Dindarlığın Bedelleri ve Faydaları Üzerine Bir Değerlendirme”. çev. Ali Ulvi Mehmedoğlu. Çukurova Üniversitesi İlahiyat Fakültesi Dergisi 5/1 (OcakHaziran 2005), 279-313.

Sheehy, Noel vd. Biographical Dictionary of Psychology. New York: Routledge, 2002,

Spilka, Bernard vd. "Din Psikolojisi Açısından Genel Bir Atıf Teorisi". çev. Ali Kuşat. Journal for the Scientific Study of Religion 24/1 (1985), 173-195.

Şentürk, Mücahit. Sakarya Halkının Kader Anlayışı. Sakarya: Sakarya Üniversitesi, Sosyal Bilimler Enstitüsü, Yüksek Lisans Tezi, 2013.

Ülgener, Sabri. Zihniyet ve Din-İslam, Tasavvufve Çözülme Devri İktisat Ahlakı. İstanbul: Der Yayınları, 1981.

Ümmet, Durmuş. “Üniversite Mezunu Evli Bireylerin Evlilik Algıları Üzerine Metaforik Bir İnceleme”. Kalem Eğitim ve İnsan Bilimleri Dergisi 7/1 (2017), 205-235.

Yaparel, Recep. "Depresyon ve Dinî İnançlar ile Tabiatüstü Nedensel Yüklemeler Arasındaki İlişkiler”. Dokuz Eylül Üniversitesi İlahiyat Fakültesi Dergisi 8 (1994), 275-299.

Yapıcı, Asım. “Kovid-19 Küresel Salgınına Dinî ve Din Dışı Yüklemeler, Tanrı'nın Gazabı mı? İnsanın Suçu mu?”. Küresel Salgınlara Farklı Bakışlar. ed. Ejder Okumuş. Ankara: Eski Yeni Yayınları, 2020.

Yavuz, Yusuf Şevki. "Kader". Türkiye Diyanet Vakfı İslam Ansiklopedisi. 24/58-63. İstanbul: TDV Yayınlar1, 2001.

Yavuz, Yusuf Şevki. "Levh-i Mahfuz". Türkiye Diyanet Vakfi İslam Ansiklopedisi. 27/151. Ankara: TDV Yayınları, 2003.

Yıldız, Mualla. Suç ve Yükleme. Ankara: Grafiker Yayınları, 2020. 